KFKI-1985-25

L. VASAROS

$\mathrm{K}$. BERE I

GENERAL PROPERTIES OF ASTATINE

Hungarian Academy of Sciences

CENTRAL

RESEARCH

INSTITUTE FOR

PHYSICS

BUDAPEST 
KFKI -1985-25

\section{GENERAL PROPERTIES OF ASTATINE}

L. VASAROS and $K$. BEREI,

Central Research Institute for Physics H-1525 Budapest 114, P.O.B. 49, Hungary

Manuscript submitted to the Astatine Volume of the Gmelin Handbook 
ABSTRACT

This study represents a compilation of the general physico-chemical properties of astatine atoms and ions. Along with the data a brief account of methods for determining of the properties cited is also given. The literature search was completed in July 1984.

АННОТАЦИЯ

Дается обзор общих физико-химических свойств астата. Наряду с приводимыми в работе данными, обсуждалтся также методы определения основных свойств астата.

Литературный обзор был составлен в июле 1984 года.

\section{KIVONAT}

A tanulmányban az asztácium alapvetô fizikai-kémiai tulajdonságainak összefoglaló leirását adjuk. Az adatok közlésével együtt röviden tárgyaljuk az asztácium általános tulajdonságainak meghatározására szolgáló módszereket is.

Az irodalom gyüjtését 1984. juliusában fejeztük be. 


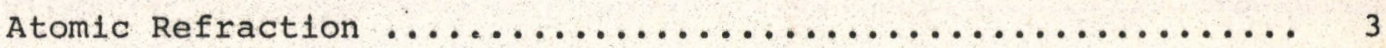

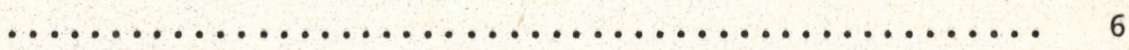

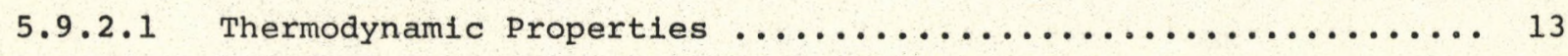

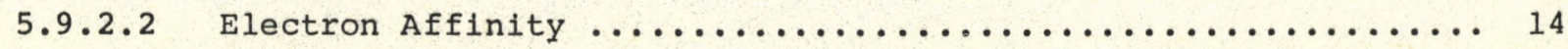

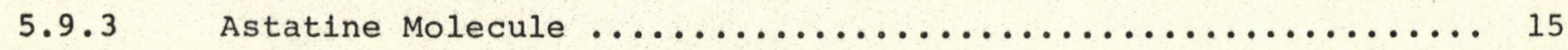

5.9.3.1 Phase Transition Properties ......................... 15

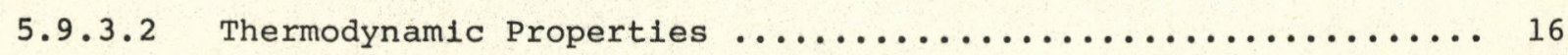

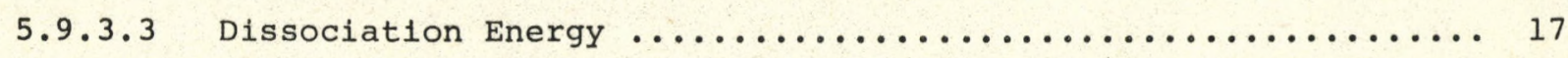

5.9.4 Positive Molecular Ion of Astatine, $\mathrm{At}_{2}{ }^{+} \ldots \ldots \ldots \ldots \ldots \ldots \ldots \ldots$

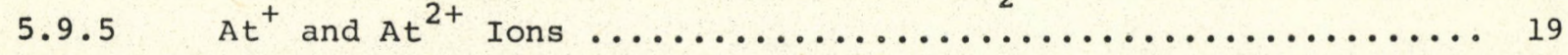

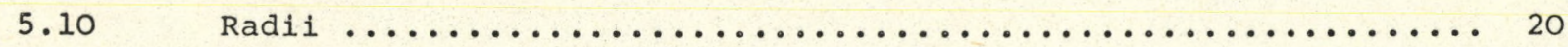

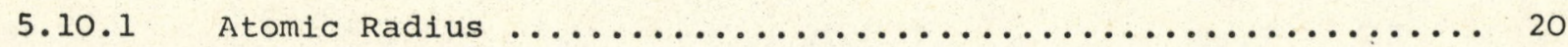

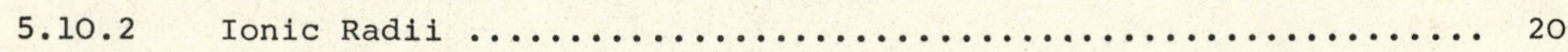


IV.

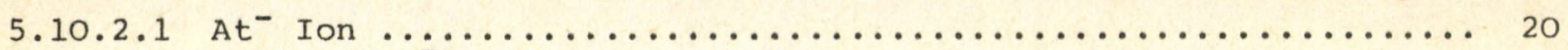

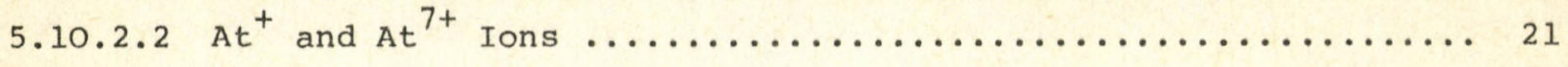

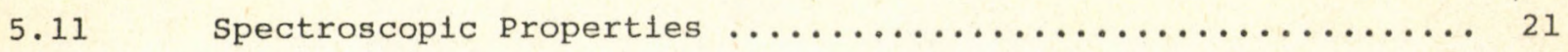

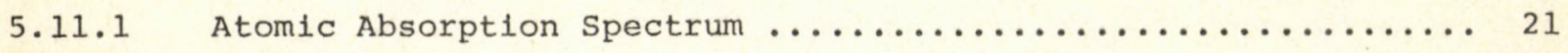

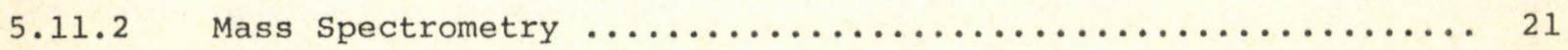

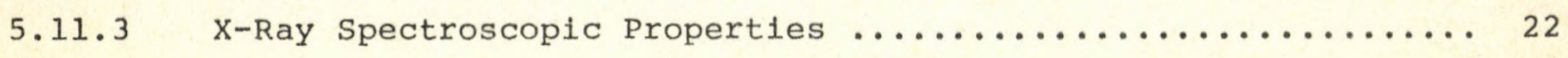

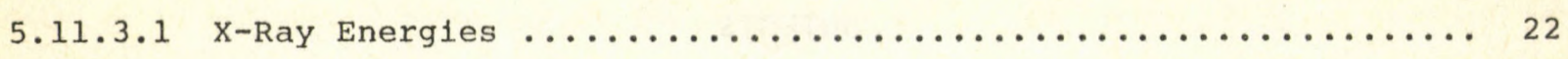

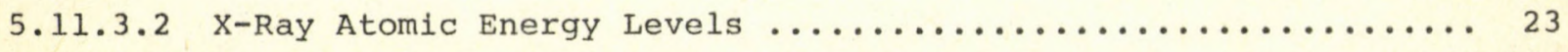

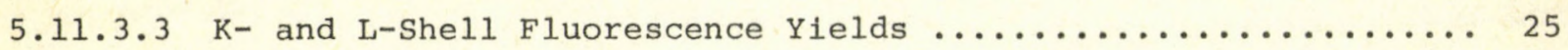

5.11.3.4 Natural Widths of Atomic $K$ and $L$ Levels and $K_{\alpha} X$-Ray Lines $\ldots 25$

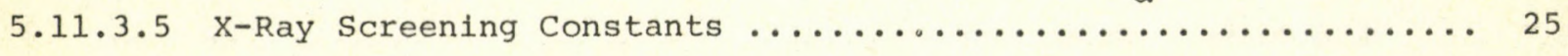

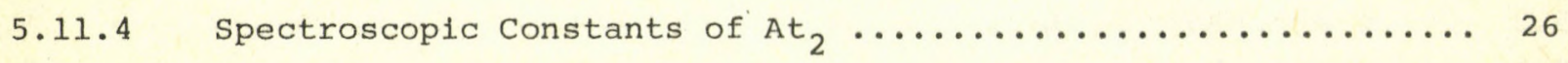

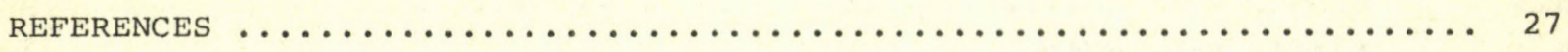


5. GENERAL PROPERTIES OF ASTATINE 
Only a very limited amount of direct evidence is available concerning the properties of astatine because it occurs naturally in trace amounts. In view of this, most of the data for astatine have been extrapolated or interpolated by various empirical or theoretical treatments from the values determined for the other halogens, or for the neighboring elements of astatine in the Periodic Table. Recent improvements in the theoretical ab initio computations have also made it possible to calculate some of the basic properties of astatine.

\subsection{Electronic Structure}

Similarly to the other halogens, the astatine atom lacks one electron to fill its valence shell. The electron configuration of the ground state astatine atom can be assigned as $[\mathrm{Xe}] 4 \mathrm{f}^{14} 5 \mathrm{~d}^{10} 6 \mathrm{~s}^{2} 6 \mathrm{p}^{5}\left({ }^{2} \mathrm{P}_{3 / 2}\right)[1,2]$.

The ground state electronic structure of astatine ions is also analogous to that for other halogens. The valence shell of astatide ion has the noble gas configuration of $6 s^{2} 6 p^{6}\left({ }^{1} s_{0}\right)$ [3]. The ground state outer electron configuration of $\mathrm{At}^{+}$ion can be assigned as $6 \mathrm{~s}^{2} 6 \mathrm{p}^{4}\left({ }^{3} \mathrm{P}_{2}\right)$. For positive atomic ions the electronic structure is given in Table 2 (see Section 5.6).

\subsection{Electronegativity}

In Pauling's original table the electronegativity $(X)$ of astatine is given as 2.2 [4]. The subsequent improved and more precise electronegativity scales give similar results $[1,5,6]$. The $X$ values based on a number of scales and calculated by different methods $[1,4$ to 9$]$ are summarized in Table 1.

Table 1. Electronegativity Values of Astatine Atom

\begin{tabular}{|l|c|c|}
\hline \multicolumn{1}{|c|}{ Method of Determination } & $X$ Values & Ref. \\
\hline Pauling Scale & 2.2 & {$[4]$} \\
Mulliken Scale & 2.4 & {$[1]$} \\
Gordy Scale & 2.2 & {$[5]$} \\
Electrostatic Forces & 1.9 & {$[6]$} \\
& 2.42 & {$[8]$} \\
Extrapolation by Mendeleev's Rule & 2.25 & {$[7]$} \\
$X=f(I)$ & 2.32 & {$[9]$} \\
\hline
\end{tabular}

Electronegativities for higher oxidation states of astatine have been calculated on the basis of electrostatic forces and were found to be 1.74 and 2.048 for $\mathrm{At}^{5+}$ and $\mathrm{At}{ }^{7+}$ ions, respectively [6]. 


\subsection{Atomic Volume}

The atomic volume for astatine has been estimated by extrapolation from the plot of atomic volume vs. period of halogens as $27.5 \mathrm{~cm}^{3} / \mathrm{gatom}$ [10]. More recently the atomic information indices, derived from the known electronic configuration of halogens, have also been used for correlation with their atomic volume. The latter value for astatine was then extrapolated from this dependence and found to be $33.9-34.5 \mathrm{~cm}^{3} /$ gatom [11].

\subsection{Atomic Refraction}

The atomic refraction calculated on the basis of the electronegativity of astatine has been found to be $19.3 \mathrm{~cm}^{3} /$ gatom [12].

\subsection{Polarizabilities}

The polarizability of astatide ion has been derived from its ionic radius and was stated to be $8.3 \times 10^{-24} \mathrm{~cm}^{3}$ [13]. Using theoretical methods of calculation, the total quadrupole polarizabilities have been estimated as $57.03699 \times 10^{-40} \mathrm{~cm}^{5}$ and $19.78638 \times 10^{-40} \mathrm{~cm}^{5}$ for the free and for the crystal astatide ions, respectively [14].

$\mathrm{Ab}$ initio calculaticns have also been performed to estimate the static dipole polarizability of neutral astatine atom in the ground state. The values obtained in this way were found to be $4.36 \times 10^{-24} \mathrm{~cm}^{3}[15,16]$, $7.88 \times 10^{-24} \mathrm{~cm}^{3}[17]$, and $5.76 \times 10^{-24} \mathrm{~cm}^{3}\left(38.9 \mathrm{Bohr}^{3}\right) *$ [18].

\subsection{Ionization Energies}

The first ionization energy $\left(I_{1}\right)$ for the element with atomic number 85 was originally derived by Finkelnburg as $9.4 \mathrm{eV}$ [19]. In subsequent papers the original value was modified to $9.5 \pm 0.2 \mathrm{eV}[20]$ and then to $9.2 \pm 0.4 \mathrm{eV}$ [21], which last value is usually quoted in the review literature [22]. This set of ionization energies was estimated by using regularities in the change of the screening constant $(\Delta \sigma)$ from element to element in the Periodic Table. From the estimated value of $\Delta \sigma=0.7$ for astatine and from the experimental $I_{1}$ quantities of adjacent to astatine elements (Po or Rn) the first ionization energy for astatine could be calculated [19 to 21]. From the linear dependence between the experimental parameter $Z^{\prime}$ for halogens - derived from gas chromatographic retention data of halogenated aliphatic compounds - and

\footnotetext{
*Originally quoted value is given in parentheses.
} 
their first ionization energy Norseyev and Nefedov have estimated the value of $I_{1}$ as $9.5 \mathrm{eV}[23]$. From the relationship between the vibrational frequency $\left(\omega_{e}\right)$ for halogen molecules and the first ionization energy of halogen atoms the value of $I_{1}$ has been estimated to be $10.4 \mathrm{eV}$ by Varshni [24] assuming clark's predicted value of $\omega_{e}=139.4 \mathrm{~cm}^{-1}$ for astatine (see Section 5.11.4). Ozhigov applied Mendeleev's rule of extrapolation to obtain $9.44 \mathrm{eV}$ for the first and $16.71 \mathrm{eV}$ for the second ionization energy of astatine atom [7]. The electron binding energy values of the outermost $P_{3}\left(6 p_{3 / 2}\right)$ subshell for the free At atom - i.e. its first ionization energy - obtained by interpolation $(9.3 \mathrm{eV})$ and by ab initio calculation $(8.6 \mathrm{eV})$, as given in Table 14 (see Section 5.11.3.2), are close to the values of $I_{1}$ mentioned above. In Parsons' Handbook of Electrochemical Constants a value of $9.6 \mathrm{eV}$ is given [25]. The estimated first and higher ionization energies for ground state astatine atom are summarized in Table 2.

Table 2. Atomic Ionization Energies of Astatine

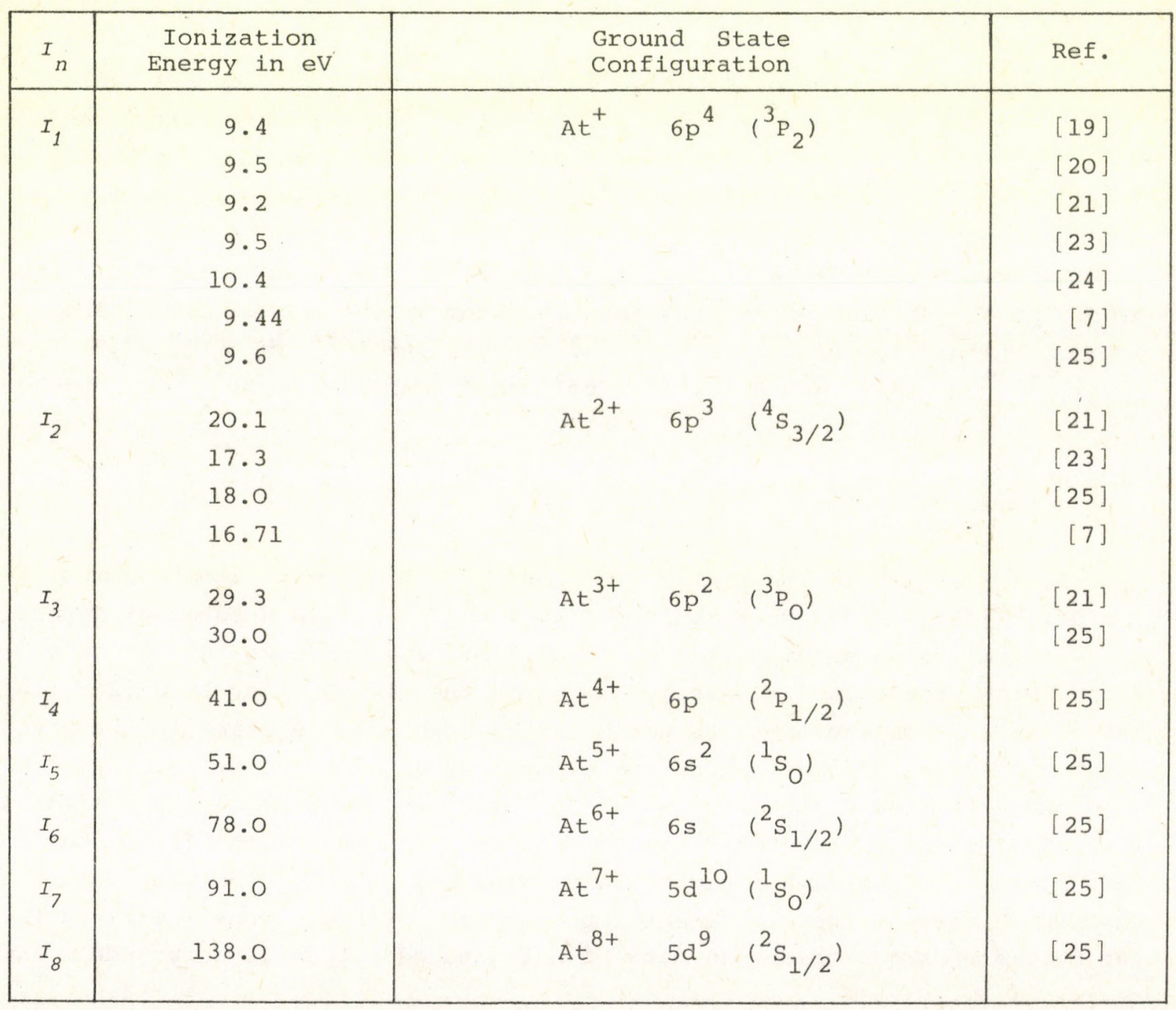


The ionization energy for molecular astatine has been estimated by Kiser as $8.3 \mathrm{eV}$ [26] in the same way as was done by Varshni [24]. In the calculation procedure the ionization energy for molecular halogens, as well as an estimated value of $\omega_{e}=160 \mathrm{~cm}^{-1}$ for $\mathrm{At}_{2}$ were used [26]. Norseyev and Nefedov, using extrapolation based on the experimental parameter $\mathrm{Z}^{\prime}$ (see above), estimated the ionization energy for molecular astatine as $8.4 \mathrm{eV}[23]$.

\subsection{Oxidation States}

From the general trend in the Periodic system, astatine is expected to possess a more electropositive character than the other halogens. Thus, the first investigators considered astatine to be a metal showing a closer resemblance to polonium than to iodine [27 to 29]. On the other hand, the volatility of astatine, its extractability with carbon tetrachloride [29], and its similarity in physiological behavior to lodine $[30,31]$ seemed to be consistent with its halogen character. Further systematic investigation of its aqueous solutions has shown that the valence states of astatine are similar to those of lodine. Johnson et al. described four oxidation states, viz. (-I), zero, and two positive valency states [32]. Appelman has confirmed and characterized (-I), zero, intermediate positive (I or III), and (V) valence states but found no evidence for the (VII) state $[33,34]$. Later, perastatate was able to be obtained by using $\mathrm{XeF}_{2}$ as the oxidizing agent [35] and also by other methods [36 to 39]. Methods of preparation for different oxidation states of astatine are described in section 10.2.1. In the following sections we review briefly the properties of these At species.

\subsubsection{Astatine $(-1)$}

The best defined valence state - astatine (-I) - has been found to be stable in acidic and basic solutions containing sufficiently strong reducing agents [ 32 to 34,40 to 45$]$. In acidic solutions without reducing agents the astatide ion may be oxidized to the zero valence state $[40,42]$. Electromigration experiments $[32,46]$, coprecipitation with insoluble iodides $[32$ to 34 , $42,47,48]$, paper electrophoresis $[38,40$ to 42$]$, paper chromatography $[36,49]$, high pressure ion exchange chromatography [43], and free solution electrophoresis $[39,45,50]$ have been used to characterize astatine (-I).

In contrast to the iodide ions, astatide has a strong tendency to adsorb on metallic silver $[42,47]$ and tellurium $[29,41,42,51]$ surfaces from acidic solutions containing reducing agents. Astatide, similarly to iodide, may be completely adsorbed on the reduced surfaces of metallic platinum from sulfuric acid solutions [52], and can also be characterized by the ability to replace halogens in simple halogenated aliphatic and aromatic compounds (see e.g. [53]). 
5.7 .2 Astatine (0)

At $(0)$ is the expected oxidation state of astatine when it is isolated by dry methods at high temperatures from bismuth after irradiation with $\alpha$-particles [32 to $34,44,54$ to 58], and from thorium or uranium targets after bombardment with high energy protons [59 to 61]. At(0) is also assumed to be the oxidation state when astatine is redistilled at $500{ }^{\circ} \mathrm{C}$ from silver and platinum surfaces in closed glass ampoules $[33,39,50,58]$.

When elemental astatine is dissolved in pure water $[38,44,58,62$ to 64$]$, or in nitric acid solutions $[32,33,65]$ the retention of the zero oxidation state is expected. The zero valence state of astatine was also supposed when it is prepared from a cyclotron-irradiated bismuth target by conventional dissolution and extraction techniques $[43,44,62$ to 64$]$.

Aqueous solutions of At (O) may be prepared by oxidation of astatide ion with dilute nitric acid, $\mathrm{Fe}^{3+}, \mathrm{I}_{2}, \mathrm{VO}_{2}^{+}, \mathrm{As}^{3+}$ at $\mathrm{pH}<5$, or $\left[\mathrm{Fe}(\mathrm{CN})_{6}\right]^{3-}$ at $\mathrm{pH}<3$ [32 to 34]. On the other hand, the zero oxidation state of astatine may also be formed from the higher oxidation states by reduction with $\mathrm{Fe}^{2+}, \mathrm{I}^{-}$, or $\mathrm{VO}^{2+}[32$ to 34$]$.

The zero oxidation state is characterized by its volatility, a tendency to be adsorbed by various metallic surfaces such as silver, gold, and platinum $[32,33,38,58,60,61]$ and less strongly by glass surfaces [33] both from vapours and solutions. At (0) can be extracted either from nitric acid solutions with isopropyl ether $[54,65,66], \mathrm{CCl}_{4}, \mathrm{C}_{6} \mathrm{H}_{6}[32,33,54], \mathrm{n}^{-} \mathrm{C}_{6} \mathrm{H}_{14}$, and $c-C_{6} \mathrm{H}_{12}[33,65]$, or from sulfuric acid solutions with $\mathrm{CHCl}_{3}[43,44,63$ to 65]. At (0) is also characterized by reduced volatility from solutions as compared with the volatility of iodine, by varying degrees of coprecipitation with metal sulfides and hydroxides [32], and with metallic silver or tellurium in situ [33]. From acidic solutions containing $\mathrm{SO}_{2}$ astatine is partially carried by TII and AgI as a result of adsorption of At(O) on the surface of precipitates $[32,33]$.

The exact chemical nature of At(O) in solutions, however, still remains uncertain. Merinis et al. - during their experiments to produce interhalogen compounds of astatine (see KFKI-1984-29) - described the astatine activity, deposited in the gradient thermochromatographic tube at $16{ }^{\circ} \mathrm{C}$, as $\mathrm{At}_{2}$ [67]. More recently Otozai and Takahashi have claimed to identify the At 2 peak by gas liquid chromatography [68]. However, as several authors have pointed out, the existence of molecular astatine is excluded by its extremely low concentration under ordinary conditions of chemical experiments [33,69 to 72]. Furthermore, the formation of $\mathrm{At}_{2}$ does not seem to be realistic because any reaction which tends to split the $A t_{2}$ molecule becomes thermodynamically favored at these low concentrations [65]. It is also unlikely that the zero valence state of astatine is present as a true At radical because of the assumed high reactivity of the latter $[33,71]$. Since iodine is always present in excess, Aten supposed that in aqueous solutions At(O) exists as AtI [69]. 
A similar conclusion has been drawn by Visser and Diemer from their extraction experiments with At(0) [72]. Other authors have assumed that At (0) in aqueous solutions may react with organic impurities forming organic astatine compounds the exact nature of which depends on the medium $[33,34,65,71,73]$. Meyer et al. have investigated the reactivity of At $(0)$, dissolved in neutral aqueous solutions, with simple aromatic compounds. For benzene and chlorobenzene the hydrogen and chlorine substitution yields did not exceed 1\%. A higher hydrogen replacement yield (49\%) was observed with aniline [63, 64 ].

In the presence of elemental chlorine, bromine, and iodine the zero oxidation state of astatine is represented by AtCl, AtBr, and AtI. These diatomic interhalogen compounds have been prepared both in solution and in the gaseous state $[33,44,48,63,64,69,74$ to 76$]$, and have been characterized by their extractibility with organic solvents $[33,48,69,74]$ and by their deposition temperature [67].

\subsubsection{Astatine(1)}

The time-of-flight spectrometry measurements of Appelman et al. have demonstrated the existence of $\mathrm{At}^{+}$ions in the gaseous phase (see Section 5.11.2). This is so far the only direct method to identify any of the oxidation states of astatine [75]. The mass spectrum of $\mathrm{At}^{+}$is shown in Fig. 1. Later, Golovkov et al. also detected $\mathrm{At}^{+}$, formed in the plasma ion source of a mass separator, by its radioactivity [76].

Fig. 1

Mass spectrum of $A t^{+}$ and other A-species

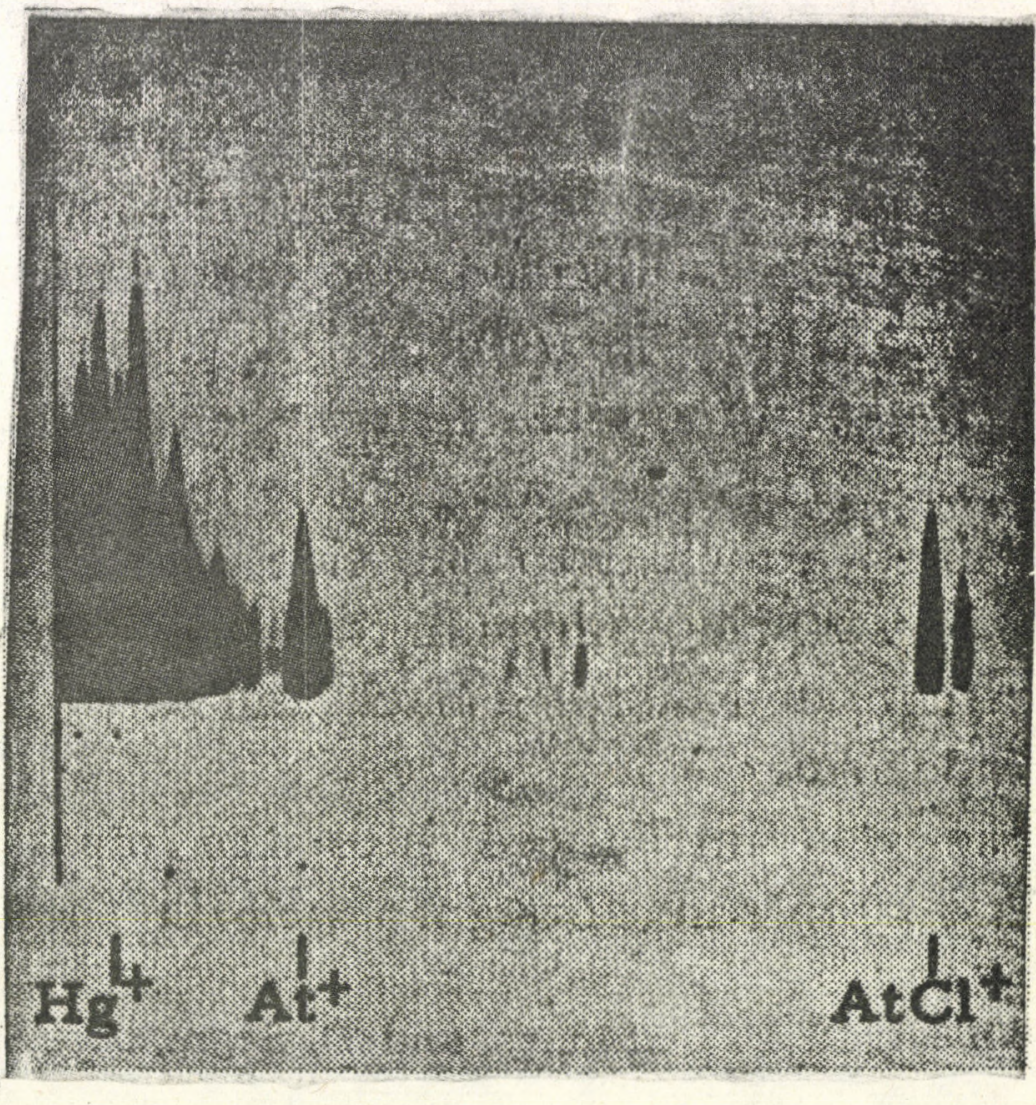


The monovalent cationic form of astatine can be obtained and stabilized in nitric acid solutions containing $\mathrm{Cr}_{2} \mathrm{O}_{7}{ }^{2-}$ as the oxidizing agent. The positive charge of astatine(I) species has been established by free solution electrophoresis $[46,50,77]$, while its monovalent character by ion exchange chromatography $[43,77,78]$.

The astatine(I) state has been assumed to be responsible for the formation of complex anions $\mathrm{AtX}_{2}^{-}(\mathrm{X}=\mathrm{Cl}, \mathrm{Br}, \mathrm{I}, \mathrm{SCN}, \mathrm{CN}$, thiourea or its derivatives) $[54,79$ to 84$]$. From the results of numerous experiments $[46,50$, 77 to 82,85 to 88 ] Khalkin et al. concluded that astatine(I) in acidic solutions containing $\mathrm{Cr}_{2} \mathrm{O}_{7}{ }^{2-}$ can form a stable aquacomplex $\left[\left(\mathrm{H}_{2} \mathrm{O}\right){ }_{x} \mathrm{At}\right]^{+}(\mathrm{x}=1$ or 2$)$ [86 to 88]. This assumption is well in line with the earlier findings of Neumann [54] and with the recent experimental results on the hydrogen substitution reactions of astatine with simple aromatic compounds. From the positive results of aromatic $\mathrm{H}$-replacement the existence of $\left[\mathrm{H}_{2} \mathrm{OAt}\right]^{+}$, as an electrophilic species, could also be concluded [89].

\section{7 .4 Astatine $(111)$}

For the anionic species formed by oxidation of astatine with elemental bromine, the probable oxidation state of At(III) has been assumed $[32,33]$. From the migration rates measured by free solution electrophoresis Dreyer et al. have proposed the existence of $\mathrm{AtO}^{+}$or $\mathrm{H}_{2} \mathrm{AtO}_{2}{ }^{+}, \mathrm{AtO}_{2}{ }^{-}$, and $\mathrm{AtOx}_{2}{ }^{-}$ $(\mathrm{X}=\mathrm{Cl}, \mathrm{Br}$, and $\mathrm{I})$ species. In order to study the mobilities of these ions, At(III) state was obtained by oxidation of At(O) with $\mathrm{S}_{2} \mathrm{O}_{8}{ }^{2-}$ in $\mathrm{HClO}_{4}$ solutions or with $\mathrm{XeF}_{4}$ in neutral medium $[36,39,50,82]$. In the course of investigating the properties of inorganic astatine species under oxidative conditions, Visser and Diemer suppose that with n-dibutyl ether from $\mathrm{S}_{2} \mathrm{O}_{8}{ }^{2-}$ and $\mathrm{H}_{2} \mathrm{O}_{2}$ solutions, etherates containing the At(III) moiety are extracted. The expressed complex forming ability of astatine(III) is also discussed by these authors [72].

In the compounds of $\mathrm{ArAtCl}_{2}$ and $\mathrm{Ar} 2 \mathrm{AtCl}$ ( $\mathrm{Ar}=\mathrm{C}_{6} \mathrm{H}_{5}$ or $\mathrm{p}-\mathrm{CH}_{3} \mathrm{C}_{6} \mathrm{H}_{4}$ ) synthesized by Norseyev et al., the At(III) state was obtained by oxidation of At(-I) with $\mathrm{Cl}_{2}[90,91]$ (see KFKI-1984-29).

\subsubsection{Astatine (V)}

The $\mathrm{AtO}_{3}^{-}$anion belongs to the well characterized chemical form of astatine(V). This ionic species can be formed from the lower oxidation states under stronger oxidation conditions (i.e. in hot solutions containing the oxidizing agent) [32 to 34,37 to 40,50 ] or by acidifying the $\mathrm{AtO}_{4}^{-}$ containing solutions [39]. 
$\mathrm{AtO}_{3}^{-}$ion was originally characterized by its tendency to coprecipitate with $\mathrm{AgIO}_{3}[32$ to 34$], \mathrm{Ba}\left(\mathrm{IO}_{3}\right)_{2}$, and $\mathrm{Pb}\left(\mathrm{IO}_{3}\right)_{3}[33,34]$. This interpretation became doubtful when the At(I) state was also shown to coprecipitate with the insoluble iodates [80]. Identification by peper chromatography, paper electrophoresis $[38,40]$, and by free solution electrophoresis $[39,50]$ made the existence of the $\mathrm{AtO}_{3}^{-}$anion certain.

In the organometallic compounds of $\mathrm{ArAtO}_{2}\left(\mathrm{Ar}=\mathrm{C}_{6} \mathrm{H}_{5}\right.$ or $\left.\mathrm{p}-\mathrm{CH}_{3} \mathrm{C}_{6} \mathrm{H}_{4}\right)$ the central astatine atom has an oxidation state of At(V). These compounds have been prepared by Norseyev et al. by oxidation of $\mathrm{ArAtCl}_{2}$ with hot NaOCl solution $[90,91]$.

\subsubsection{Astatine (VII)}

The perastatate ion, $\mathrm{AtO}_{4}^{-}$, was first prepared by Khalkin et al. by oxidizing $\mathrm{At}^{-}$with $\mathrm{XeF}_{2}$ in a hot alkaline solution [35], in the same way that the formation of perbromate was carried out shortly before [92]. The $\mathrm{AtO}_{4}^{-}$anion was identified and characterized by paper electrophoresis and by its coprecipitation with potassium and cesium metaperiodate [35]. Later anodic oxidation [36] or oxidation with $\mathrm{KIO}_{4}$ in neutral or alkaline solu-

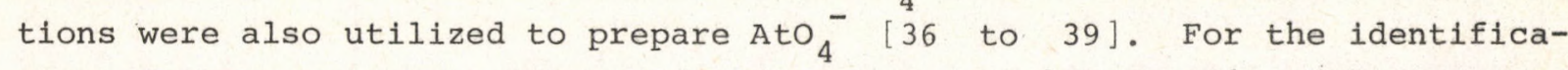
tion of the perastatate ion, paper chromatography $[35,36,38]$, paper electrophoresis [38], and free solution electrophoresis $[39,50]$ have been applied. $\mathrm{AtO}_{4}^{-}$, similarly to $\mathrm{IO}_{4}^{-}$, is stable only in neutral and alkaline solutions. By means of heating in an acidic medium the reduction of perastatate into astatate is completed in several minutes $[38,39]$.

\subsection{Electrochemical Properties}

\subsubsection{Critical Deposition Potentials}

The critical deposition potentials of astatine both at the cathode and anode from different aqueous solutions have been determined by Johnson et al. and are summarized in Tables 3 and 4 . These values were obtained by extrapolation of deposition rates vs. potential curves to zero rate. The chemical forms of deposited At species in the electrolytic experiments were not determined [32]. 
Table 3. Critical Deposition Potentials of Astatine at the Cathode [32]

\begin{tabular}{|l|c|c|}
\hline \multicolumn{1}{|c|}{ Solution } & $\begin{array}{c}\text { At Concentration } \\
\text { in pM }\end{array}$ & $\begin{array}{c}\text { Potential } \\
\text { in V Vs. NHE* }\end{array}$ \\
\hline $0.066 \mathrm{M} \mathrm{HNO}_{3}$ & 0.28 & -1.225 \\
$1.0 \mathrm{M} \mathrm{HNO}_{3}$ & 0.05 & -1.240 \\
$0.075 \mathrm{M} \mathrm{H}_{2} \mathrm{SO}_{4}+0.1 \mathrm{M} \mathrm{Na}_{2} \mathrm{Cr}_{2} \mathrm{O}_{7}$ & 0.60 & -1.200 \\
$0.006 \mathrm{M} \mathrm{HNO}_{3}+3 \mathrm{mg} \mathrm{Au}$ & 0.10 & -1.220 \\
$0.066 \mathrm{M} \mathrm{HNO}_{3}$ & 0.04 & -1.220 \\
\hline
\end{tabular}

${ }^{*}$ NHE $=$ normal hydrogen electrode.

Table 4. Critical Deposition Potentials of Astatine at the Anode [32]

\begin{tabular}{|l|c|c|}
\hline \multicolumn{1}{|c|}{ Solution } & $\begin{array}{c}\text { At Concentration } \\
\text { in pM }\end{array}$ & $\begin{array}{c}\text { Potential } \\
\text { in V vs. NHE* }\end{array}$ \\
\hline $0.066 \mathrm{M} \mathrm{HNO}_{3}$ & 0.24 & -1.460 \\
$0.066 \mathrm{M} \mathrm{HNO}_{3}$ & 0.53 & -1.450 \\
$0.100 \mathrm{M} \mathrm{HNO}_{3}+0.1 \mathrm{M} \mathrm{K}_{2} \mathrm{~S}_{2} \mathrm{O}_{8}$ & 0.54 & -1.445 \\
\hline
\end{tabular}

*NHE = normal hydrogen electrode.

\subsubsection{Standard Electrode Potentials}

On the basis of potentials of the redox couples employed by Johnson et al. for preparing the oxidation states of At(-I), At(O), At(I), and At(V) [32], Latimer has constructed the first tentative standard electrode potential diagrams (in V) for astatine [93]:

Acidic Solution

$$
\mathrm{HAtO}_{3} \stackrel{+1.4}{\longrightarrow} \text { HAtO } \stackrel{+0.7}{\longrightarrow} \mathrm{At}_{2} \stackrel{+0.2}{\longrightarrow} \mathrm{At}^{-}
$$

Basic Solution

$$
\mathrm{AtO}_{3}^{-} \stackrel{+0.5}{\longrightarrow} \mathrm{AtO}^{-} \stackrel{\mathrm{O} .0}{\longrightarrow} \mathrm{At}_{2} \stackrel{+\mathrm{O} .2}{\longrightarrow} \mathrm{At}^{-}
$$


However, the uncertain potentials of the systems studied by Johnson et al. [32], as well as the problematic nature of the chemical form of At (0) (see Section 5.7.2) make Latimer's potential diagram questionable. Later, in a more systematic study with suitably chosen redox couples Appelman determined the following reduction potential diagram for At(-I), At(O), At(I?), At (V), At(VII?) oxidation states in $0.1 \mathrm{M}$ acid at $25^{\circ} \mathrm{C}$ :

$$
\mathrm{H}_{5} \mathrm{AtO}_{6}(?) \stackrel{+1.6}{\longrightarrow} \mathrm{AtO}_{3}^{-} \stackrel{+1.5}{\longrightarrow} \mathrm{HOAt}(?) \stackrel{+1.0}{\longrightarrow} \mathrm{At}(\mathrm{O}) \stackrel{+0.3}{\longrightarrow} \mathrm{At}^{-}
$$

The exact valence of the positive oxidation state (or states) between At $(O)$ and At (V) could not be determined, and no evidence for At(VII) state was found at that time $[33,34]$.

The standard electrode potential for At(O)/At(-I) couple has been estimated by Mendeleev's rule of extrapolation as $0.457 \mathrm{~V}$ [7]. More recently, ion exchange chromatography at a fixed redox potential has also been used to determine standard potentials for different redox couples of astatine. The potential values obtained by this technique were found to be $0.335 \mathrm{~V}$ at $323 \mathrm{~K}$ and $0.85 \mathrm{~V}$ at $332 \mathrm{~K}$ for the At (O)/At(-I) and At $(\mathrm{x}) / \mathrm{At}(0)$ couples, respectively [94]. For the latter couple, At(x) represents an intermediate oxidation state between At $(\mathrm{O})$ and $\mathrm{At}(\mathrm{V})$.

\subsection{Thermodynamic Data}

The thermodynamic properties of astatine species have solely been able to be estimated by various theoretical and empirical calculations. Data on enthalpies, Gibbs free energies, entropies, and other thermodynamic properties of individual inorganic and organic astatine compounds are dealt with in KFKI-1984-29. Here, the thermodynamic data for different astatine species are summarized.

\subsection{1 $\mathrm{At}^{-}$ION}

Enthalpies, Gibbs free energies, entropies, and heat capacities at constant pressure for gaseous and hydrated $\mathrm{At}^{-}$ions are summarized in Table 5 . The heat of formation for gaseous $\mathrm{At}^{-}$was first evaluated by Ladd and Lee from the $\Delta \mathrm{H}_{\mathrm{f}}^{\mathrm{O}}$ values for gaseous alkali metal astatides by using the BornHaber cycle $[95]$. Another $\Delta \mathrm{H}_{\mathrm{f}}^{\circ}$ value for gaseous $A t^{-}$has been estimated from the lattice energy of alkali metal halides vs. $\Delta H_{f}^{\circ}$ for a gaseous halide ions plot [96]. The entropy of gaseous $A t^{-}$was calculated by using the SackurTetrode equation [96]. In Table 5 the thermodynamic data for gaseous $\mathrm{At}^{-}$from the Handbook of Thermal Constants [97] are also given. 
Table 5. Thermodynamic Data for Gaseous and Hydrated At at $298.15 \mathrm{~K}$

\begin{tabular}{|c|c|c|c|c|c|}
\hline \multirow{2}{*}{$A t^{-}$} & $\Delta \mathrm{H}_{\mathrm{f}}^{\mathrm{O}}$ & $\Delta \mathrm{G}_{\mathrm{f}}^{\mathrm{O}}$ & $\mathrm{s}^{\mathrm{O}}$ & $C_{p}^{O}$ & \multirow{2}{*}{ Ref. } \\
\hline & \multicolumn{2}{|c|}{$\begin{array}{l}\text { in } \mathrm{kJ} / \mathrm{mol} \\
(\mathrm{kcal} / \mathrm{mol})^{*}\end{array}$} & \multicolumn{2}{|c|}{$\begin{array}{l}\text { in } \mathrm{J} \mathrm{K}^{-1} \text { gatom }^{-1} \\
\left(\mathrm{cal} \mathrm{K}^{-1} \text { gatom }^{-1}\right)^{*}\end{array}$} & \\
\hline \multirow[t]{3}{*}{ Gaseous } & $\begin{aligned} &-196.6 \\
&(-47.0)\end{aligned}$ & & & & [95] \\
\hline & $\begin{array}{r}-190.8 \\
(-45.6)\end{array}$ & $\begin{array}{r}-255 \\
(-53.8)\end{array}$ & $\begin{array}{l}175.5 \\
\quad(41.95)\end{array}$ & & [96] \\
\hline & $\begin{array}{r}-178 \cdot 66 \\
(-42.7)\end{array}$ & $\begin{array}{r}-202.47 \\
(-48.391)\end{array}$ & $\begin{array}{l}175.4 \\
\quad(41.93)\end{array}$ & $\begin{array}{l}20.79 \\
(4.968)\end{array}$ & [97] \\
\hline Hydrated & $\begin{array}{l}-8.4 \\
(-2.0)\end{array}$ & $\begin{array}{r}-7.95 \\
(-1.9)\end{array}$ & $\begin{array}{l}125.5 \\
(30.0)\end{array}$ & & [96] \\
\hline
\end{tabular}

The heat of formation for hydrated $\mathrm{At}^{-}$has been deduced from calculated heat of hydration and heat of formation for gaseous At ${ }^{-}$[96].

The entropy of astatide ion in a crystalline lattice has been given as $67.78 \mathrm{~J} \mathrm{~K}^{-1}$ gatom $^{-1}\left(16.2 \mathrm{cal} \mathrm{K}^{-1}\right.$ gatom $\left.^{-1}\right) *[98]$.

Krestov has calculated the change of thermodynamic functions on hydration for astatide ion in a series of papers [98 to 100]. The results are given below:

\begin{tabular}{|c|c|c|c|}
\hline & Properties & Values & Ref. \\
\hline$\Delta \mathrm{H}_{\text {hydr }}$ & $\begin{array}{l}\text { in } \mathrm{kJ} / \text { gatom } \\
\text { (kcal/gatom)* }\end{array}$ & $\begin{array}{r}182.42 \\
(43.6)\end{array}$ & [99] \\
\hline$\Delta \mathrm{S}_{\text {hydr }}$ & $\begin{array}{l}\text { in } \mathrm{J} \mathrm{K}^{-1} \text { gatom }^{-1} \\
\left(\text { cal } \mathrm{K}^{-1} \text { gatom }^{-1} \text { )* }\right.\end{array}$ & $\begin{array}{r}-107.95 \\
(-25.8)\end{array}$ & [98] \\
\hline$\left(\Delta C_{p}\right)$ hydr & $\begin{array}{l}\text { in } \mathrm{J} \mathrm{K}^{-1} \text { gatom }^{-1} \\
\left(\text { cal } \mathrm{K}^{-1} \text { gatom }^{-1}\right)^{*}\end{array}$ & $\begin{array}{r}-66.94 \\
(-16.0)\end{array}$ & [ 100 ] \\
\hline
\end{tabular}

An empirical method, based on the effective charge on the astatide ion, has been used to determine the heats of solvation $\left(\Delta \mathrm{H}_{\text {solv }}\right)$ for $\mathrm{At}^{-}$in different organic solvents [10l]. The $\Delta \mathrm{H}_{\text {solv }}$ values for aliphatic alcohols are given below together with the entropy changes on solvation $\left(\Delta \mathrm{S}_{\mathrm{solv}}\right)$ in these alcohols evaluated by Krestov [102].

\footnotetext{
*originally quoted values are given in parentheses.
} 


\begin{tabular}{|c|c|c|c|c|c|}
\hline & Properties & $\mathrm{CH}_{3} \mathrm{OH}$ & $\mathrm{C}_{2} \mathrm{H}_{5} \mathrm{OH}$ & $\mathrm{n}-\mathrm{C}_{3} \mathrm{H}_{7} \mathrm{OH}$ & Ref. \\
\hline$\Delta_{\text {solv }}$ & in $\mathrm{kJ} /$ gatom & 322.4 & 297.3 & 288.9 & [ 101] \\
\hline$\Delta \mathrm{S}_{\mathrm{solv}}$ & $\begin{array}{l}\text { in } \mathrm{J} \mathrm{K}^{-1} \text { gatom }^{-1} \\
\left(\operatorname{cal~} \mathrm{K}^{-1} \text { gatom }^{-1}\right)^{*}\end{array}$ & $\begin{array}{r}-120.5 \\
(-28 \cdot 8)\end{array}$ & $\begin{array}{r}-135 \cdot 14 \\
(-32 \cdot 3)\end{array}$ & & [ 102 ] \\
\hline
\end{tabular}

\subsubsection{Astatine Atom}

\subsubsection{Thermodynamic Properties}

The fundamental thermodynamic properties for the gaseous astatine atom, taken from the literature $[96,97,103]$, are summarized in Table 6 and show good agreement. In addition to the properties given in Table 6 , the compilation of data by Stull and Sinke gives also the enthalpy, free energy function, and the logarithm of the equilibrium constant of formation for the temperature range $298.15 \mathrm{~K}$ to $3000 \mathrm{~K} \mathrm{[103].}$

Table 6. Thermodynamic Properties of Gaseous Astatine Atom at 298.15 K

\begin{tabular}{|c|c|c|c|}
\hline Properties & [96] & [97] & [ 103$]$ \\
\hline $\begin{aligned} \Delta \mathrm{H}_{\mathrm{f}}^{\mathrm{O}} & \text { in } \mathrm{kJ} / \text { gatom } \\
& (\mathrm{kcal} / \text { gatom }) *\end{aligned}$ & 92 & $\begin{array}{l}97.24 \\
\quad(23.24)\end{array}$ & $\begin{array}{l}92.048 \\
(22.000)\end{array}$ \\
\hline $\begin{array}{ll}\Delta G_{f}^{\circ} & \text { in } \mathrm{kJ} / \text { gatom } \\
& (\mathrm{kcal} / \text { gatom }) *\end{array}$ & $\begin{array}{l}54 \\
\text { (13) }\end{array}$ & $\begin{array}{l}59.576 \\
\quad(14.239)\end{array}$ & $\begin{array}{l}54.400 \\
(13.002)\end{array}$ \\
\hline $\begin{array}{l}\mathrm{S}^{0} \quad \text { in } \mathrm{J} \mathrm{K}^{-1} \text { gatom }^{-1} \\
\left(\text { cal } \mathrm{K}^{-1} \text { gatom }^{-1}\right)^{*}\end{array}$ & $\begin{array}{l}187 \\
(44.7)\end{array}$ & $\begin{array}{r}186.98 \\
(44.69)\end{array}$ & $\begin{array}{r}186.94 \\
(44.68)\end{array}$ \\
\hline $\begin{array}{l}\mathrm{C}_{\mathrm{p}}^{\mathrm{O}} \text { in } \mathrm{J} \mathrm{K}^{-1} \text { gatom }^{-1} \\
\left(\mathrm{cal} \mathrm{K} \mathrm{K}^{-1} \text { gatom }^{-1}\right)^{*}\end{array}$ & & $\begin{array}{l}20.79 \\
\quad(4.968)\end{array}$ & $\begin{array}{l}20.79 \\
(4.97)\end{array}$ \\
\hline
\end{tabular}

The entropy for the solid state astatine atom has been estimated by Krestov as $60.67 \mathrm{~J} \mathrm{~K}^{-1}$ gatom $^{-1}\left(14.5 \mathrm{cal} \mathrm{K}^{-1}\right.$ gatom $\left.^{-1}\right) *$ [96].

\footnotetext{
* Originally quoted values are given in parentheses.
} 


\subsubsection{Electron Affinity}

The classical method of determining electron affinity (EA) from the selected $\Delta \mathrm{H}_{\mathrm{f}}^{\mathrm{O}}$ quantities for gaseous astatine atom and $\mathrm{At}^{-}[97]$ results in a value of $-276.39 \mathrm{~kJ} /$ gatom at $298.15 \mathrm{~K}$. In similar calculations, the value $\Delta H_{f}^{O}(A t)=0.5 D\left(A t_{2}\right)-D\left(A t_{2}\right)$ is the dissociation energy of molecular astatine (see Section 5.9.3.3) - was used by Ladd and Lee, instead of the heat of formation for the astatine atom. The EA value given by these authors as $-255.22 \mathrm{~kJ} / \mathrm{gatom}(-61 \mathrm{kcal} / \mathrm{gatom})$ * [95] is, therefore, to be considered not quite correct.

The atomic electron affinity of astatine has also been estimated by using different extrapolation methods $[3,7,96]$, semiempirical [23] and empirical relationships [104], and theoretical ab initio calculations [105]. The EA value for astatine recommended by Hotop and Lineberger is given in [106]. The data are summarized in Table 7. With the exception of ab initio calculations, the atomic electron affinity values for astatine estimated by different methods are in reasonable agreement with those determined from thermodynamic data.

Table 7. Calculated Electron Affinity Values for Astatine

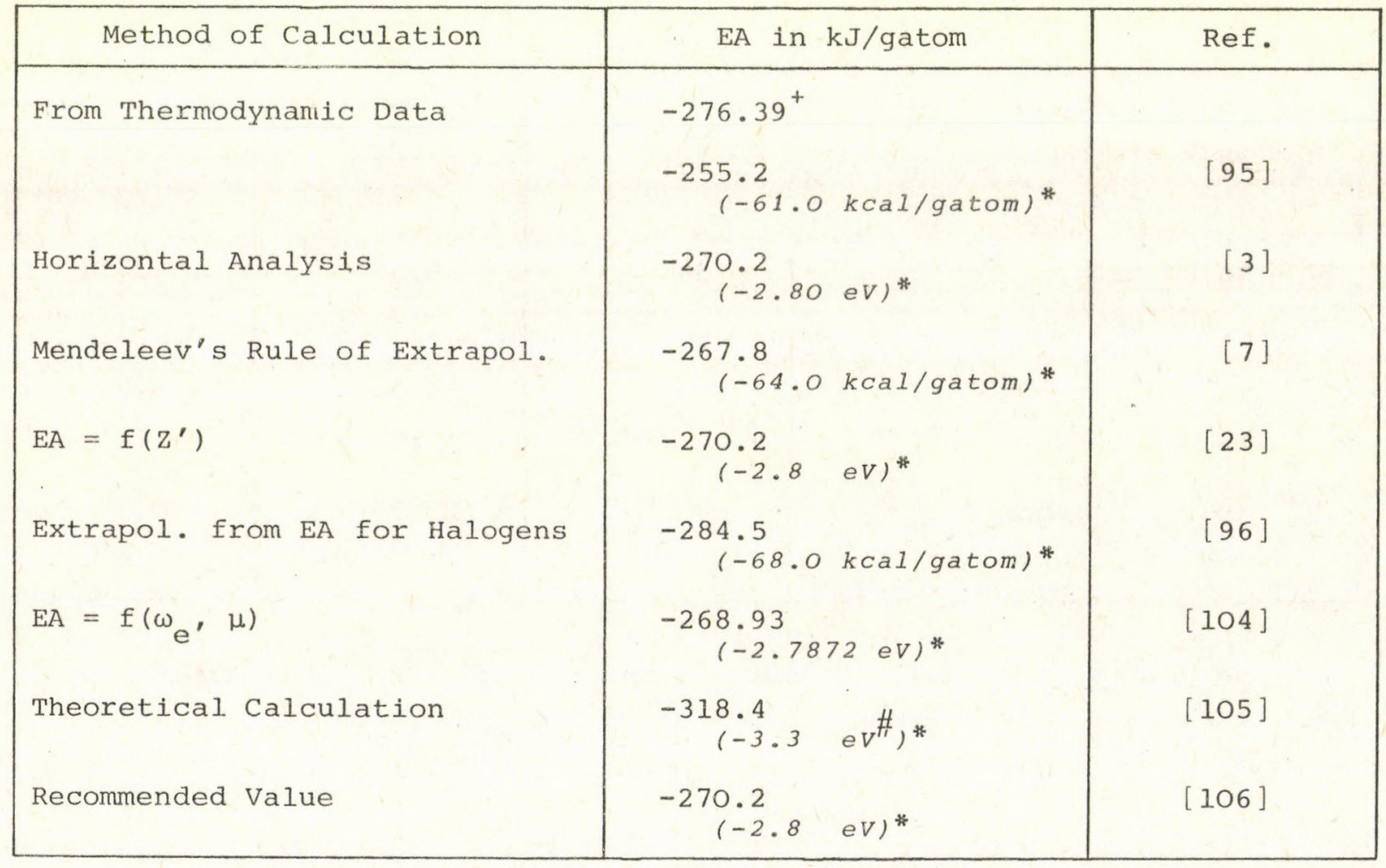

\footnotetext{
*Originally quoted values are given in parentheses. ${ }^{+}$Calculated from tabulated data for $\Delta H_{f}^{\circ}$ values [97]. \#Approximated value derived from histogram bars.
} 
The entropy change of atomic electron affinity $\left(\Delta \mathrm{S}_{E A}\right)$ for astatine has been calculated by Krestov who deduced a value $\Delta S_{E A}=-41.99 \mathrm{~J} \mathrm{~K}^{-1}$ gatom $^{-1}$ $\left(-10.036 \mathrm{cal} \mathrm{K}^{-1}\right.$ gatom $\left.^{-1}\right)$ * from the entropies of the gaseous astatine atom and $\mathrm{At}^{-}$, the entropy of free electronic gas, and the entropy change on mixing [107].

\subsubsection{Astatine Molecule}

Although the existence of $\mathrm{At}_{2}$ in typical chemical experiments so far remains uncertain (see section 5.7.2), many of its thermodynamic properties have been predicted. These data may be useful in further searches for the astatine molecule.

\subsubsection{Phase Transition Properties}

Melting and boiling temperatures $\left(T_{m}\right.$ and $\left.T_{b}\right)$, enthalpy and entropy changes on phase transitions $(\Delta H$ and $\Delta S$ ) for the astatine molecule are listed in Table 8. Durand's prediction belongs to the first determinations of the physicochemical properties of astatine. His extrapolation was based upon the nearly linear dependence of $\mathrm{T}_{\mathrm{m}}$ and $\mathrm{T}_{\mathrm{b}}$ for noble gases and $\mathrm{H}_{2}$ on the melting and boiling temperatures of halogen molecules in the corresponding rows of the Periodic Table. The value of $684 \mathrm{~K}$ for $\mathrm{T}_{\mathrm{m}}$ however, seems to be unrealistic being higher than that for $\mathrm{T}_{\mathrm{b}}$ [108]. Ozhigov's $\mathrm{T}_{\mathrm{m}}$ and $\mathrm{T}_{\mathrm{b}}$ values have been extrapolated on the basis of Mendeleev's rule [7] and are in reasonable agreement with those given in different compilations [97,103,109, 110]. The $\mathrm{T}_{\mathrm{m}}$ and $\mathrm{T}_{\mathrm{b}}$ values estimated by Norseyev and Nefedov using the empirical parameter $\mathrm{Z}^{\prime}$ are somewhat lower compared with other corresponding data given in Table 8 . However, the enthalpy of vaporization at the boiling temperature was found by these authors to be similar [23] to that given in the Handbook of Thermal Constants [97].

Recently, Otozai and Takahashi determined the boiling temperature for $\mathrm{At}_{2}$ from the GLC absolute retention volume and obtained $503 \pm 3 \mathrm{~K}[68]$. The $\mathrm{T}_{\mathrm{b}}$ value determined by these authors is significantly lower than those given in Table 8 and does not seem to be reliable because of the uncertainty of the existence of $\mathrm{At}_{2}$ (see sections 5.7.2 and 10.2.1.3.1), under the given experimental conditions.

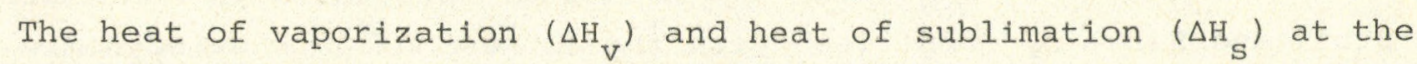
melting point for $\mathrm{At}_{2}$ have been estimated by correlation of these quantities for halogens with their atomic numbers. The $\Delta \mathrm{H}_{\mathrm{v}}$ and $\Delta \mathrm{H}_{\mathrm{s}}$ values obtained in this way, as well as the literature value of the heat of melting $\left(\Delta \mathrm{H}_{\mathrm{m}}\right)$ were then adjusted using the relation $\Delta \mathrm{H}_{\mathrm{m}}=\Delta \mathrm{H}_{\mathrm{S}}-\Delta \mathrm{H}_{\mathrm{v}}$. The data estimated by* Gerasimov et al. are given below [111].

* Originally quoted value is given in parentheses. 


$$
\begin{aligned}
\Delta \mathrm{H}_{\mathrm{m}}=17.57 \mathrm{~kJ} / \mathrm{mol} & (2.1 \mathrm{kcal} / \mathrm{gatom}) * \\
\Delta \mathrm{H}_{\mathrm{S}}=67.78 \mathrm{~kJ} / \mathrm{mol} & (8.1 \mathrm{kcal} / \mathrm{gatom}) * \\
\Delta \mathrm{H}_{\mathrm{v}}=50.21 \mathrm{~kJ} / \mathrm{mol} & (6.0 \mathrm{kcal} / \text { gatom }) *
\end{aligned}
$$

\begin{tabular}{|c|c|c|c|c|}
\hline $\begin{array}{c}\text { Phase } \\
\text { Transition }\end{array}$ & $\mathrm{T}$ in $\mathrm{K}$ & $\begin{array}{l}\Delta \mathrm{H} \text { in } \mathrm{kJ} / \mathrm{mol} \\
(\mathrm{kcal} / \mathrm{mol})^{*}\end{array}$ & $\begin{array}{l}\Delta \mathrm{S} \text { in } \mathrm{J} \mathrm{K}^{-1} \mathrm{~mol}^{-1} \\
\left(\mathrm{cal} \mathrm{K}^{-1} \mathrm{~mol}^{-1}\right)^{*}\end{array}$ & Ref. \\
\hline Cryst. - Liquid & $\begin{array}{l}684 \\
505.5 \\
473 \\
500 \\
575 \\
573 \\
575\end{array}$ & $\begin{array}{c}20.92 \\
(5.0) \\
23.85 \\
(5.70)\end{array}$ & $\begin{array}{r}41.84 \\
(10)\end{array}$ & $\begin{array}{r}{[108]} \\
{[7]} \\
{[23]} \\
{[97]} \\
{[103]} \\
{[109]} \\
{[110]}\end{array}$ \\
\hline Cryst. $\rightarrow$ Gas & $\begin{array}{l}0 \\
298.15\end{array}$ & $\begin{array}{r}86.61 \\
(20.7) \\
83.68 \\
(20.0)\end{array}$ & $\begin{array}{r}280.75 \\
(67.1)\end{array}$ & $\begin{array}{l}{[97]} \\
{[97]}\end{array}$ \\
\hline Liquid $\rightarrow$ Gas & $\begin{array}{l}572 \\
582 \\
543 \\
590 \\
650 \\
608 \\
610\end{array}$ & $\begin{array}{c}50.21 \\
(12.0) \\
54.39 \\
(12.0) \\
90.37 \\
(21.6)\end{array}$ & $\begin{array}{l}92.05 \\
(22.0)\end{array}$ & $\begin{array}{r}{[108]} \\
{[7]} \\
{[23]} \\
{[97]} \\
{[103]} \\
{[109]} \\
{[110]}\end{array}$ \\
\hline
\end{tabular}

Table 8. Thermodynamic Data of Phase Transitions for $\mathrm{At}_{2}$

\subsubsection{Thermodynamic Properties}

The thermodynamic functions for molecular astatine have been estimated by Stull and Sinke by comparison with the corresponding thermodynamic properties of other halogens. In their compilation the data of the reference state and ideal gaseous state for $\mathrm{At}_{2}$ over the entire temperature range from $298.15 \mathrm{~K}$ to $3000 \mathrm{~K}$ are tabulated [103]. In the Handbook of Thermal Constants

*originally quoted values are given in parentheses. 
the selected and calculated values of the fundamental thermodynamic properties for crystalline solid and ideal gaseous $\mathrm{At}_{2}$ at $298.15 \mathrm{~K}$ are given [97]. The enthalpy and Gibbs free energy of formation, entropy, and heat capacity at constant pressure for crystalline solid and ideal gaseous $\mathrm{At}_{2}$ at $298.15 \mathrm{~K}$ from these two sources $[97,103]$ are given in Table 9. The heat of formation for $\mathrm{At}_{2}$ has also been estimated by Kaganyuk on the basis of the effective charge on astatine; he has obtained the value $\Delta_{\mathrm{f}}^{\mathrm{O}}=87.9 \mathrm{~kJ} / \mathrm{mol}$ [101].

Table 9. Thermodynamic Properties of $\mathrm{At}_{2}$ at $298.15 \mathrm{~K}$

\begin{tabular}{|c|c|c|c|c|c|}
\hline & \multirow{2}{*}{ Properties } & \multicolumn{2}{|c|}{ Cryst. Solid } & \multicolumn{2}{|c|}{ Ideal Gas } \\
\hline & & [97] & [ 103$]$ & [97] & [ 103$]$ \\
\hline$\Delta \mathrm{H}_{f}^{\circ}$ & $\begin{array}{l}\text { in } \mathrm{kJ} / \mathrm{mol} \\
(\mathrm{kcal} / \mathrm{mol})^{*}\end{array}$ & 0 & 0 & $\begin{array}{l}83.68 \\
(20.0)\end{array}$ & $\begin{array}{l}90.37 \\
(21.6)\end{array}$ \\
\hline$\Delta G_{f}^{\circ}$ & $\begin{array}{l}\text { in } \mathrm{kJ} / \mathrm{mol} \\
(\mathrm{kcal} / \mathrm{mol})\end{array}$ & 0 & 0 & $\begin{array}{l}40.145 \\
(9.595)\end{array}$ & $\begin{array}{l}44.217 \\
(10.568)\end{array}$ \\
\hline$S^{\circ}$ & $\begin{array}{l}\text { in } \mathrm{J} \mathrm{K}^{-1} \mathrm{~mol}^{-1} \\
\left(\mathrm{cal} \mathrm{K} \mathrm{Kol}^{-1}\right)^{*}\end{array}$ & $\begin{array}{l}121.34 \\
\quad(29.0)\end{array}$ & $\begin{array}{l}121.34 \\
\quad(29.0)\end{array}$ & $\begin{array}{l}267.36 \\
\quad(63.9)\end{array}$ & $\begin{array}{l}276.14 \\
\quad(66.0)\end{array}$ \\
\hline$C_{p}^{O}$ & $\begin{array}{l}\text { in } \mathrm{J} \mathrm{K}^{-1} \mathrm{~mol}^{-1} \\
\left(\mathrm{cal} \mathrm{K}^{-1} \mathrm{~mol}^{-1}\right)^{*}\end{array}$ & $\begin{array}{l}54.39 \\
(13.0)\end{array}$ & $\begin{array}{l}58.58 \\
(14.0) .\end{array}$ & $\begin{array}{l}37.07 \\
\quad(8.86)\end{array}$ & $\begin{array}{r}33.47 \\
(8.0)\end{array}$ \\
\hline
\end{tabular}

Similar results were obtained by Kharitonov et al. using a statistical thermodynamic approach for determining the thermodynamic functions for gaseous molecular astatine. Estimated values of interatomic distance and vibrational frequency (see Section 5.11.4) were used to calculate the enthalpy $\left(\mathrm{H}_{\mathrm{T}}^{\mathrm{O}}-\mathrm{H}_{\mathrm{O}}^{\circ}\right)$, internal energy $\left(\mathrm{U}_{\mathrm{T}}^{\circ}-\mathrm{U}_{\mathrm{O}}^{\circ}\right)$, reduced isobar potential $\Phi$, absolute entropy, and heat capacity at constant pressure for the temperature range from $298.15 \mathrm{~K}$ to $1000 \mathrm{~K}$ [112]. These data are given in Table 10.

\subsubsection{Dissociation Energy}

From the decreasing tendency of dissociation energy (D) with increasing atomic number for molecular halogens (with the exception of $F_{2}$ ), the $D$ value for $\mathrm{At}_{2}$ is expected to be the lowest in this group of elements. Most of the dissociation energy data for $\mathrm{At}_{2}$ have been estimated by using various

\footnotetext{
*Originally quoted values are given in parentheses.
} 
Table 10. Thermodynamic Functions for At 2 Calculated by Statistical Thermodynamic Approach [112]

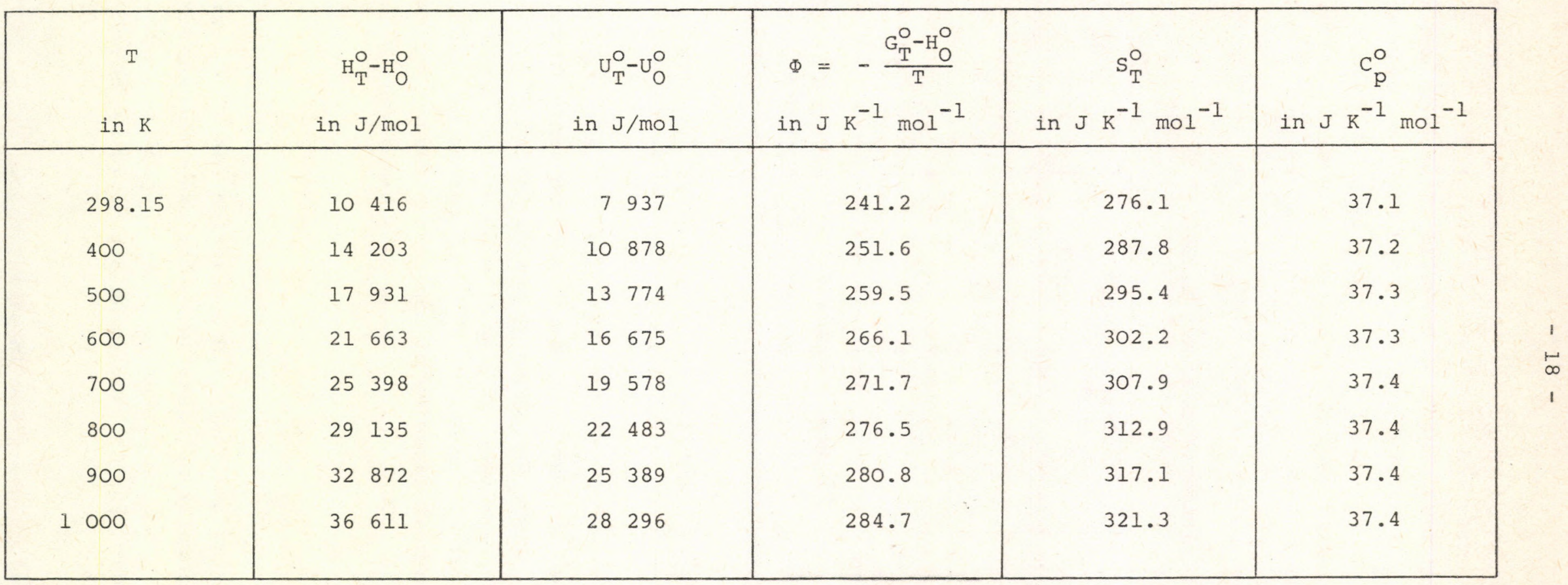


empirical correlations connecting the $D$ values for halogens with their other properties, such as ionization energy $(I)$ [26], atomic number ( $Z$ ) [113], period $[113,114]$, and experimental parameter ( $\left.Z^{\prime}\right)$ [23] (see Section 5.6). Theoretical calculations of dissociation energy for $\mathrm{At}_{2}$ have also been performed [115]. The D values from these sources are summarized in Table 11 .

Table 1l. Calculated Values of Dissociation Energy for $\mathrm{At}_{2}$

\begin{tabular}{|c|c|c|}
\hline $\begin{array}{l}\text { Method of } \\
\text { Calculation }\end{array}$ & $\begin{array}{c}\text { Dissociation Energy } \\
\text { in } \mathrm{kJ} / \mathrm{mol}\end{array}$ & Ref. \\
\hline $\lg D=f(\lg I)$ & $\begin{array}{r}115.78 \\
(1.2 \mathrm{eV})^{*}\end{array}$ & [26] \\
\hline$D=f(Z)$ & $\begin{array}{r}77.19 \\
(0.8 \text { eV })^{*}\end{array}$ & [113] \\
\hline$D=f($ Period $)$ & $\begin{array}{r}77.19 \\
(0.8 \text { eV })^{*}\end{array}$ & [ 113 ] \\
\hline & $\begin{array}{l}96.23 \\
(23.0 \mathrm{kcal} / \mathrm{mol})^{*}\end{array}$ & [114] \\
\hline$D=f\left(Z^{\prime}\right)$ & $\begin{array}{l}112.13 \\
(26.8 \mathrm{kcal} / \mathrm{mol})\end{array}$ & [23] \\
\hline Theoretical & $\begin{array}{l}75.31 \\
(18.0 \mathrm{kCal} / \mathrm{mol}) \text { * }\end{array}$ & [115] \\
\hline Thermodynamic & $\begin{array}{l}108.78 \\
(26 \mathrm{kcal} / \mathrm{mol})^{*}\end{array}$ & [97] \\
\hline
\end{tabular}

\subsubsection{Positive Molecular Ion of Astatine, $\mathrm{At}_{2}{ }^{+}$}

For this ionic species the enthalpy of formation has been deduced from the ionization energy of $\mathrm{At}_{2}$ (see Section 5.6) as $887 \mathrm{~kJ} / \mathrm{mol}(212 \mathrm{kcal} / \mathrm{mol}$ )* [97].

The dissociation energy for $\mathrm{At}_{2}{ }^{+}$has been derived from the thermodynamic cycle of dissociation and ionization and was found to be $231.56 \mathrm{~kJ} / \mathrm{mol}$ $(2.4 \mathrm{eV})^{*}[26]$. A similar estimation with selected values for the dissociation energy of $\mathrm{At}_{2}$, and the atomic and molecular ionization energies of astatine gave a value of $193.966 \mathrm{~kJ} / \mathrm{mol}$ (46.359 kcal/mol)* [97].

$5.9 .5 \mathrm{At}^{+}$and $\mathrm{At}^{2+}$ lons

The heat of formation for gaseous $\mathrm{At}^{+}$and $\mathrm{At}^{2+}$ ions has been deduced from their ionization energies $[96,97]$, and is given below.

* Originally quoted values are given in parentheses. 


\begin{tabular}{|c|c|c|}
\hline \multirow{2}{*}{ Species } & $\Delta \mathrm{H}_{\mathrm{f}}^{\mathrm{O}}$ in $\mathrm{kJ} / \mathrm{mol}$ & $(\mathrm{kcal} / \mathrm{mol})^{*}$ \\
\cline { 2 - 3 } & {$[96]$} & {$[97]$} \\
\hline \multirow{2}{*}{$\mathrm{At}^{+}$} & $1 \mathrm{OOO4}$ & $\begin{array}{c}983 \\
(240)\end{array}$ \\
\multirow{2}{*}{$\mathrm{At}^{2+}$} & $2 \underset{235)}{761}(660)$ & 2084 \\
& $(498)$ \\
\hline
\end{tabular}

\subsection{Radii}

\subsection{0 .1 Atomic Radius}

The atomic radius ( $R$ ) for astatine has been evaluated as $0.146 \mathrm{~nm}$ using Mendeleev's rule of extrapolation [7]. Estimation from the linear plot of atomic radii for halogens vs. their experimental parameter $Z^{\prime}$ (see section 5.6) leads to a value of $0.145 \mathrm{~nm}$ [23]. The values of $0.119 \mathrm{~nm} \mathrm{[17]} \mathrm{and}$ $0.127 \mathrm{~nm}$ [116] have been obtained by theoretical ab initio calculations.

5.10 .2 Ionic Radii

$5.10 .2 .1 \mathrm{At}^{-}$ION

The radius ( $r$ ) for the gaseous astatide ion has been estimated from the constancy of the ratio of radii for the isoelectronic ion pairs. The value of $0.197 \mathrm{~nm}$ calculated in this way by Krestov [96] seems to be low compared with those for other halogens given by Krasnov as $0.112 \mathrm{~nm}$ for $\mathrm{F}^{-}, 0.1683 \mathrm{~nm}$ for $\mathrm{Cl}^{-}, 0.1864 \mathrm{~nm}$ for $\mathrm{Br}^{-}$, and $0.2119 \mathrm{~nm}$ for $\mathrm{I}^{-}$gaseous ions [117].

Different methods have been applied to estimate the ionic.crystal radius for $\mathrm{At}^{-}[7,23,96,118$ to 121$]$. The methods and the results of these calculations are summarized in Table 12 .

Table 12. Calculated Values of Ionic Crystal Radius for At ${ }^{-}$

\begin{tabular}{|c|c|c|}
\hline Method of Calculation & Radius in $\mathrm{nm}$ & Ref. \\
\hline From Interionic Distance & 0.227 & [117] \\
\hline Mendeleev's Rule & 0.226 & [ 7] \\
\hline$r=f(l g z)$ & $\begin{array}{l}0.234 \\
0.261\end{array}$ & $\left.\begin{array}{l}{\left[\begin{array}{ll}1 & 18\end{array}\right]} \\
119\end{array}\right]$ \\
\hline$r=f\left(r_{X^{-}}\right) x=$ Halogen & 0.230 & [96] \\
\hline$r=f\left(z^{\prime}\right)$ & 0.229 & [23] \\
\hline$r=f$ (Lattice Energy) & 0.222 & [120] \\
\hline
\end{tabular}

*Originally quoted value are given in parentheses. 
$5.10 \cdot 2 \cdot 2 \mathrm{At}^{+}$and $\mathrm{At}^{7+}$ Ions

Extrapolation according to Mendeleev's rule has been used to determine the radius of the gaseous $\mathrm{At}^{+}$ion. The value obtained in this way was found to be $0.061 \mathrm{~nm}[7]$. From the ratio $r_{A t^{+}} / R_{A t}=0.28$ determined by Korablev [122], the radius of $\mathrm{At}^{+}$can be estimated as $0.041 \mathrm{~nm}$ if one uses Ozhigov's value for the atomic radius of $0.146 \mathrm{~nm}$ [7].

The radius of $\mathrm{At}^{7+}$ has been evaluated by making use of the smooth regularity between radius and charge for isoelectronic ions. From the sequence $\mathrm{Au}^{+}, \mathrm{Hg}^{2+}, \mathrm{Tl}^{3+}, \mathrm{Pb}^{4+}$, and $\mathrm{Bi}^{5+}$ the extrapolated value for $\mathrm{At}^{7+}$ was found to be $0.062 \mathrm{~nm}$ [123]. Norseyev and Nefedov estimated the radius of At ${ }^{7+}$ as $0.06 \mathrm{~nm}$ [23]. In Parsons' Handbook of Electrochemical Constants a value of. $0.062 \mathrm{~nm}$ is given [25].

\section{11 Spectroscopic Properties}

\subsubsection{Atomic Absorption Spectrum}

The ability to detect the atomic absorption spectrum is one of the very few ways of obtaining direct information on astatine. Using a highly sensitive spectroscopic detection method, McLaughlin was able to measure the absorption spectrum of astatine atoms. His method included the adaptation of capillary-absorption-cell spectroscopy, which allowed the detection of as little as $0.2 \mathrm{ng}$ of gaseous astatine. The temperature of the quartz capillary absorption cell was kept at $600{ }^{\circ} \mathrm{C}$ to enhance the decomposition of molecules that might have contained astatine. In order to prove which of the recorded lines belongs to astatine, the intensities were monitored as a function of time. The decrease of line intensities for $244.401 \mathrm{~nm}$ and $216.225 \mathrm{~nm}$ were found to be consistent with the radioactive decay of astatine. The two astatine lines were assigned by extrapolation from the lowest absorption lines for lighter halogens. The lines $224.401 \mathrm{~nm}$ and $216.225 \mathrm{~nm}$ were assigned to the transitions ${ }^{2} \mathrm{P}_{3 / 2} \rightarrow{ }^{4} \mathrm{P}_{5 / 2}$ and ${ }^{2} \mathrm{P}_{3 / 2} \rightarrow{ }^{4} \mathrm{P}_{3 / 2}$, respectively, between electron configurations $6 \mathrm{p}^{5} \rightarrow 6 \mathrm{p}^{4} 7 \mathrm{~s}[124]$.

\subsection{1 .2 Mass Spectrometry}

Using a highly sensitive ( 40 atom $\left./ \mathrm{cm}^{3}\right)$ time-of-flight spectrometer, Appelman et al. have directly detected the mass spectra of some astatine containing ions, such as $\mathrm{At}^{+}, \mathrm{HAt}^{+}, \mathrm{CH}_{3} \mathrm{At}{ }^{+}$, and $\mathrm{AtX}^{+}-\mathrm{X}=\mathrm{Cl}, \mathrm{Br}, \mathrm{I}-$ even though no evidence for $\mathrm{At}_{2}{ }^{+}$and $\mathrm{AtF}^{+}$ions could be obtained [75].

More recently Golovkov et al. - using a mass separator with plasma ion source - detected the following ionic species: $\mathrm{AtH}^{+}, \mathrm{AtOH}^{+}, \mathrm{AtOH}_{2}^{+}, \mathrm{AtX}^{+}$ $(\mathrm{X}=\mathrm{Cl}, \mathrm{Br}, \mathrm{I})$, and $\mathrm{At}_{2}{ }^{+}$from their radioactivity. The formation of $\mathrm{At}_{2}{ }^{+}$ 
was explained as the result of a heterolytic reaction between $\mathrm{At}^{+}$and $\mathrm{At}(\mathrm{O})$ at the outlet of the plasma ion source. The existence of $\mathrm{At}_{2}{ }^{+}$in this mass spectroscopic study was interpreted by means of its higher dissociation energy value compared with that of At 2 [76].

When introducing chlorine or bromine into the ion source in both cases two lines of $\mathrm{AtCl}^{+}$and $\mathrm{AtBr}^{+}$could be observed with relative intensities corresponding to the relative abundance of stable halogen isotopes in question $[75,76]$.

\section{$5.11 .3 \mathrm{X}$-Ray Spectroscopic Properties}

\section{$5.11 .3 .1 \mathrm{X}$-Ray Energies}

In the electron capture branch of neutron-deficient radon isotopes, e.g.

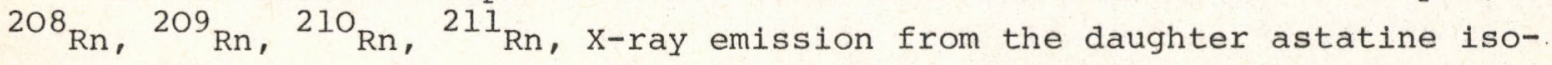
topes is to be expected. Indeed, $\mathrm{x}$-rays with energies characteristic for astatine $\left(\mathrm{K}_{\alpha_{2}}=78.945 \mathrm{keV}, \mathrm{K}_{\alpha_{1}}=81.516 \mathrm{keV}\right.$, and $\left.\mathrm{K}_{\beta_{1}}=92.30 \mathrm{keV}\right)$ have been detected in the low energy region of $\gamma$-spectra $[125,126]$. Besides the experimental results, X-ray data for astatine can be found in a number of tables with computed values of $\mathrm{x}$-radiation energies for the heavier elements (see e.g. [127 to 129]). The $\mathrm{X}$-ray energies of the principal $\mathrm{K}$ and $\mathrm{L}$ spectral lines for astatine, determined by interpolation - taken from the most frequently cited source, i.e. Bearden's X-Ray Wavelengths compilation [129], are summarized in Table 13. The relative intensities of these lines are also given in this table [127]. A complete tabulation of $\mathrm{K}$ and $\mathrm{L} \mathrm{X}$-ray energies and of their relative intensities for astatine can be found in [127]. 
Table 13. The $\mathrm{K}$ and $\mathrm{L} \mathrm{X}$-Ray Energies for Astatine

\begin{tabular}{|c|c|c|c|}
\hline \multicolumn{2}{|c|}{ Designation } & $\begin{array}{c}\mathrm{X} \text {-Ray Energy } \\
\text { in keV } \\
{[129]}\end{array}$ & \multirow[t]{2}{*}{$\begin{array}{c}\text { Relative Intensities } \\
\text { in o } \\
{[127]}\end{array}$} \\
\hline \multicolumn{3}{|c|}{$K-s$ e $r i$ e s } & \\
\hline & $\mathrm{KL}_{2}$ & 78.95 & 60.3 \\
\hline & $\mathrm{KL}_{3}$ & 81.52 & 100.0 \\
\hline$\beta_{3}$ & $\mathrm{KM}_{2}$ & 91.72 & 11.3 \\
\hline$\beta_{1}$ & $\mathrm{KM}_{3}$ & 92.30 & 22.0 \\
\hline $\mathrm{B}_{2}^{\mathrm{II}}$ & $\mathrm{KN}_{2}$ & 94.84 & 2.72 \\
\hline$\beta_{2}^{I}$ & $\mathrm{KN}_{3}$ & 94.99 & 5.41 \\
\hline \multicolumn{4}{|c|}{$L-s$ e $r i$ e $s$} \\
\hline & $L_{1} M_{3}$ & 14.0670 & 33.55 \\
\hline & $\mathrm{L}_{2} \mathrm{M}_{4}$ & 13.8760 & 131.50 \\
\hline & $\mathrm{L}_{2} \mathrm{~N}_{4}$ & 16.2510 & 27.95 \\
\hline & $\mathrm{L}_{3} \mathrm{M}_{4}$ & 11.3048 & 11.40 \\
\hline$\alpha_{1}$ & $\mathrm{~L}_{3} \mathrm{M}_{5}$ & 11.4268 & $\begin{array}{l}100.0 \\
(5.21) *\end{array}$ \\
\hline
\end{tabular}

*Relative intensity of the $L_{\alpha_{1}}$ line with respect to $K_{\alpha_{1}}=100 \%$.

5.11 .3 .2 X-Ray Atomic Energy Levels

Most of available atomic electron binding energy $\left(E_{b}\right)$ values for ground state astatine have been estimated by interpolation in $\mathrm{z}$ between the experimental binding energies of neighboring elements [127,128,130 to 133]. The $\mathrm{X}$-ray atomic electron binding energy levels, given in Table 14, are taken from the compilation of Sevier [132]. Electron binding energies for neutral astatine atoms have also been determined by theoretical ab initio calculations [134 to 136]. The theoretical data of Huang et al. [135] are also included in Table 14. The $\mathrm{E}_{\mathrm{b}}$ values for free astatine atom, deduced from the $\mathrm{X}$-ray data, are given in the last column of Table 14 [133]. It can be seen from these data that the theoretically calculated electron binding energy values are closer to those determined for the free astatine atom. 
Table 14. Atomic Electron Binding Energies for Astatine

\begin{tabular}{|c|c|c|c|c|c|c|}
\hline & \multirow{2}{*}{ Level } & \multicolumn{5}{|c|}{$-\mathrm{E}_{\mathrm{b}}$ in $\mathrm{eV}$} \\
\hline & & To $F \in$ & $\begin{array}{l}\text { rmi Level } \\
132]\end{array}$ & $\begin{array}{c}\text { Theor Calc. } \\
{[135]}\end{array}$ & In & $\begin{array}{l}\text { Free Atom } \\
{[133]}\end{array}$ \\
\hline K & $\left(1 s_{1 / 2}\right)$ & & 724.0 & 95721.9 & & $95 \quad 729$ \\
\hline $\mathrm{L}_{1}$ & $\left(2 \mathrm{~s}_{1 / 2}\right)$ & & 481.5 & 17496.0 & & 17490 \\
\hline $\mathrm{L}_{2}$ & $\left(2 \mathrm{p}_{1 / 2}\right)$ & & 777.3 & 16781.4 & & 16782 \\
\hline $\mathrm{L}_{3}$ & $\left(2 p_{3 / 2}\right)$ & & 208.0 & 14213.4 & & $14 \quad 212$ \\
\hline$M_{1}$ & $\left(3 s_{1 / 2}\right)$ & & 311.7 & 4335.9 & & 4320 \\
\hline $\mathrm{M}_{2}$ & $\left(3 p_{1 / 2}\right)$ & & 995.8 & 4009.2 & & 4005 \\
\hline$M_{3}$ & $\left(3 p_{3 / 2}\right)$ & & 410.5 & 3423.1 & & 3420 \\
\hline $\mathrm{M}_{4}$ & $\left(3 d_{3 / 2}\right)$ & & 901.8 & 2909.6 & & 2910 \\
\hline$M_{5}$ & $\left(3 d_{5 / 2}\right)$ & & 780.7 & 2788.7 & & 2788 \\
\hline $\mathrm{N}_{1}$ & $\left(4 s_{1 / 2}\right)$ & & 038.2 & 1054.9 & & 1044 \\
\hline $\mathrm{N}_{2}$ & $\left(4 p_{1 / 2}\right)$ & & 897.7 & 912.7 & & 904 \\
\hline $\mathrm{N}_{3}$ & $\left(4 \mathrm{p}_{3 / 2}\right)$ & & 753.7 & 765.2 & & 761 \\
\hline $\mathrm{N}_{4}$ & $\left(4 d_{3 / 2}\right)$ & & 527.6 & 538.1 & & 535 \\
\hline $\mathrm{N}_{5}$ & $\left(4 d_{5 / 2}\right)$ & & 500.1 & 510.6 & & 508 \\
\hline $\mathrm{N}_{6}$ & $\left(4 f_{5 / 2}\right)$ & & 207.0 & 212.6 & & 217 \\
\hline $\mathrm{N}_{7}$ & $\left(4 \mathrm{f}_{7 / 2}\right)$ & & 200.8 & 206.3 & & 211 \\
\hline $\mathrm{O}_{1}$ & $\left({ }^{5 s_{1 / 2}}\right)$ & & 193.4 & 206.6 & & 196 \\
\hline $\mathrm{O}_{2}$ & $\left(5 p_{1 / 2}\right)$ & & 145.6 & 154.3 & & 153 \\
\hline $\mathrm{O}_{3}$ & $\left(5 p_{3 / 2}\right)$ & & 113.6 & 124.4 & & 123 \\
\hline $\mathrm{O}_{4}$ & $\left(5 d_{3 / 2}\right)$ & & 40.9 & 47.9 & & 48 \\
\hline $\mathrm{O}_{5}$ & $\left(5 d_{5 / 2}\right)$ & & 37.4 & 43.9 & & 44 \\
\hline & $\left(6 s_{1 / 2}\right)$ & & 15.0 & 24.5 & & 19 \\
\hline $\mathrm{P}_{2}$ & $\left(6 p_{1 / 2}\right)$ & & 5.7 & 11.9 & & 11 \\
\hline $\mathrm{P}_{3}$ & $\left(6 p_{3 / 2}\right)$ & & 2.8 & 8.6 & & 9.3 \\
\hline
\end{tabular}




\section{$5.11 .3 .3 \mathrm{~K}$ - and $\mathrm{L}-\mathrm{Shell} \mathrm{Fluorescence} \mathrm{Yields}$}

The K-shell fluorescence yield $\left(\omega_{K}\right)$ has been estimated as 0.971 [137] and 0.969 [138]. The high value of $\omega_{\mathrm{K}}$ indicates the high probability that a vacancy in the $\mathrm{K}$-shell of astatine is filled via radiative transition. Theoretical calculations on the L-shell fluorescence yields have given the following results: $\omega_{L_{1}}=0.129[139], \omega_{L_{2}}=0.422$, and $\omega_{L_{3}}=0.380[140]$. Similar values can be found in Krause's compilation: $\omega_{L_{1}}=0.128, \omega_{L_{2}}=0.415$, and $\omega_{L_{3}}=0.399[138]$.

5.11 .3 .4 Natural Widths of Atomic $K$ and $L$ Levels and $K_{\alpha} X-R a y$ Lines

Semi-empirical values of natural widths for $K, L_{1}, L_{2}$, and $L_{3}$ levels, have been estimated for atomic astatine from its corresponding theoretical radiative rate and estimated fluorescence yield. $\mathrm{K}_{\alpha_{1}}$ and $\mathrm{K}_{\alpha_{2}} \mathrm{x}$-ray line widths were calculated as the sum of the widths of the levels involved in the transition [141]. The semi-empirical values of the natural widths for astatine atom are given below.

\begin{tabular}{|cccc|cc|}
\hline \multicolumn{7}{|c|}{ Natural Widths in eV } \\
\hline $\mathrm{K}$ & $\mathrm{L}_{1}$ & $\mathrm{~L}_{2}$ & $\mathrm{~L}_{3}$ & $\mathrm{~K}_{\alpha_{1}}$ & $\mathrm{~K}_{\alpha_{2}}$ \\
\hline 69.8 & 12.8 & 7.01 & 6.29 & 76.1 & 76.8 \\
\hline
\end{tabular}

\section{$5.11 .3 .5 x$-Ray Screening Constants}

$x$-Ray screening constants $\left(\sigma_{1}\right.$ and $\left.\sigma_{2}\right)$, accounting for the screening of nuclear charge due to other electrons, can be calculated by Sommerfeld's classic relativistic energy formula [142]. In order to calculate the screening parameters in the $\mathrm{X}$-ray spectra of astatine, the energy levels given by Bearden and Burr [130] were used. The value of $\sigma_{1}$ for the $\mathrm{K}$ level was estimated as 6.494 [143]; values of $\sigma_{2}$ for the $\mathrm{S}_{1 / 2}$ terms of $\mathrm{L}_{1}, \mathrm{M}_{1}$, and $\mathrm{N}_{1}$ levels are given as 2.5, 7.0, and 13.0, respectively [144]. The calculated values of $\sigma_{1}$ and $\sigma_{2}$ for various spin doublets are summarized in Table 15 [145 to 148]. 
Table 15. X-Ray Screening Constants for Various Spin Doublets of Astatine

\begin{tabular}{|c|c|c|c|c|c|}
\hline $\begin{array}{c}\text { Screening } \\
\text { Constant }\end{array}$ & $\mathrm{L}_{2} \mathrm{~L}_{3}$ & $\mathrm{M}_{2} \mathrm{M}_{3}$ & $\mathrm{M}_{4} \mathrm{M}_{5}$ & $\mathrm{~N}_{2} \mathrm{~N}_{3}$ & Ref. \\
\hline$\sigma_{1}$ & 21.549 & 39.20 & 42.52 & 57.0 & {$[145]$} \\
$\sigma_{2}$ & 3.580 & 8.64 & 13.60 & 16.7 & {$[146,147]$} \\
& 3.550 & 8.00 & 13.60 & 17.0 & {$[148]$} \\
\hline
\end{tabular}

\subsection{1 .4 Spectroscopic Constants of $\mathrm{At}_{2}$}

The ground state vibrational constant $\left(\omega_{\mathrm{e}}\right)$ for the $\mathrm{At}_{2}$ molecule was estimated using, empirical relationships, combining the $\omega_{e}$ values with different atomic and molecular properties of astatine, such as atomic number ( $\mathrm{Z}$ ) [149], ionization energy and the principal quantum number of valence electrons $(I, \mathrm{n})[150]$, electronegativity and the reduced mass $(X, \mu)[151,152]$. Theoretical calculations were also utilized $[115,153]$. The $\omega_{e}$ values for the astatine molecule are given in Table 16. Lippincott's estimation of $99.0 \mathrm{~cm}^{-1}$ [115] seems to be too low compared with the other predicted $\omega_{e}$ values for $A t_{2}$. From the sequence of ground state vibrational frequency values for other halogens [154], the estimated $\omega_{e}$ data for At 2 reported in [149 to 153] seem reasonable.

Table 16. Ground State Vibrational Constant Values for Astatine Molecule

\begin{tabular}{|l|c|c|}
\hline Method of Calculation & $\omega_{\mathrm{e}}$ in $\mathrm{cm}^{-1}$ & Ref. \\
\hline $\lg \omega_{\mathrm{e}}=\mathrm{f}(\lg 2 \mathrm{z})$ & 139.4 & {$[149]$} \\
$\lg \omega_{\mathrm{e}}=\mathrm{f}\left(\lg \mathrm{n}^{2} I\right)$ & 172.9 & {$[150]$} \\
$\omega_{\mathrm{e}}=\mathrm{f}\left(X / \mu^{\mathrm{p}}\right)$ & 139.0 & {$[151]$} \\
$\lg \omega_{\mathrm{e}}=\mathrm{f}\left(\lg X / \mu^{2}\right)$ & 132.9 & {$[152]$} \\
Theoretical & 141.0 & {$[153]$} \\
& 99.0 & {$[154]$} \\
\hline
\end{tabular}

A theoretical calculation of the ground state anharmonic vibrational constant $\left(\omega_{e} x_{e}\right)$ for the astatine molecule gave a value of $0.29 \mathrm{~cm}^{-1}$ [115].

From the $\omega_{e}$ values estimated by Clark [149] and by Tandon et al. [152], the force constant $\left(\mathrm{k}_{\mathrm{e}}\right)$ for $\mathrm{At}_{2}$ has been calculated as $1.213 \mathrm{~N} / \mathrm{cm}$ $(1.213 \mathrm{mdyn} / \AA) *$ and $1.195 \mathrm{~N} / \mathrm{cm}$ (1.195 mdyn/ $/) *$, respectively [112].

*Originally quoted values are given in parentheses. 
The interatomic distance $\left(r_{e}\right)$ for $\mathrm{At}_{2}$ has been calculated from the linear plot $\mathrm{ln}_{\mathrm{e}}$ vs. $\mathrm{r}_{\mathrm{e}}$ for halogen molecules. Using the two estimated $\mathrm{k}_{\mathrm{e}}$ values for $\mathrm{At}_{2}$ (see above), the interatomic distance was found to be $0.2967 \mathrm{~nm}$ and $0.2981 \mathrm{~nm}$ [112]. Theoretical calculations resulted in a value of $0.352 \mathrm{~nm}[115]$.

\section{REFERENCES}

[1] A.J. Downs, C.J. Adams: The Chemistry of Chlorine, Bromine, Iodine and Astatine, Pergamon, Oxford 1975 p. 1585

[2] C.E. Moore: Atomic Energy Levels, Circular NBS 467, U.S. Gov. Printing Office, Washington 1958

[3] R.J. Zollweg: J. Chem. Phys. 50 (1969) 4251/61

[4] L. Pauling: The Nature of the Chemical Bond, Cornell Univ. Press, New York 1960

[5] W. Gordy, w.J.O. Thomas: J. Chem. Phys. 24 (1956) 439/44

[6] Y. Zhang: Inorg. Chem. 21 (1982) 3886/9

[7] E.P. Ozhigov: Zh. Obshch. Khim. 34 (1964) 3519/23

[8] S.S. Batsanov: Zh. Strukt. Khim. 5 (1964) 293/301

[9] G.A. Korablev: Issled. V Obl. Fiz. Khim. Perekhodnykh Elem., Udmurt Gos. Univ., Izhevsk 1976 pp. 133/7; C.A. 90 (1979) No. 92841j

[10] K. Bächmann, P. Hoffmann: Radiochim. Acta 15 (1971) 153/63

[11] D. Bonchev, V. Kamenska: J. Phys. Chem. 85 (1981) 1177/86

[12] I.L. Agafonov: Zhur. Neorg. Khim. $\underline{4}$ (1959) 1270/6

[13] T.S. Perova, V.S. Libov: Spektrokhim. Vnutri-Mezhmol.Vzaimodeistvii $\underline{2}$ (1978) 126/35; C.A. 91 (1979) No. 29774v

[14] K.D. Sen, P.T. Narasimhan: Phys. Rev. B. 15 (1977) 95/102

[15] J. Thorhallsson, C. Fisk, S. Fraga: J. Chem. Phys. 49 (1968) 1978/8

[16] R.R. Teachout, R.T. Pack: At. Data $\underline{3}$ (1971) 195/214

[17] S. Fraga, J. Karwowski, K.M.S. Saxena: At. Data Nucl. Data Tables $\underline{12}$ (1973) $467 / 77$

[18] W.J. Stevens, M. Krauss: J. Phys. B: At. Mol. Phys. 16 (1983) 2921/30

[19] W. Finkelnburg: Z. Naturforsch. 2a (1947) 16/20

[20] W. Finkelnburg: Phys. Rev. 77 (1950) 303

[21] W. Finkelnburg, W. Humbach: Naturwissensch. $\underline{42}$ (1955) 35/7

[22] L.V. Gurvich, G.V. Karachevtsev, V.N. Kondrat'ev, Yu.A. Lebedev, V.A. Medvedev, V.K. Potapov, Yu.S. Khodeev: Energiya Razryva Khimicheskikh Svyazei. Potentsial Ionizatsii i Srodsvo k Elektronu, Nauka, Moscow 1974; C.A. 82 (1975) No. $47961 x$ 
[23] Yu.V. Norseyev*, V.D. Nefedov: Issled. Khim. Tekhnol. Primen. Radioakt. Veshestv, Leningradskii Tekhnol. Inst., Leningrad 1977 pp. 3/8; C.A. 94 (1981) No. $3539 j$

[24] Y.P. Varshni: Z. Physik 135 (1953) 512/5

[25] R. Parsons: Handbook of Electrochemical Constants, Butterworths, London 1959

[26] R.W. Kiser: J. Chem. Phys. 33 (1960) 1265/6

[27] D.R. Corson, K.R. Mackenzie, E. Segrè: Phys. Rev. 57 (1940) 459

[28] E. Segrè, K.R. Mackenzie, D.R. Corson: Phys. Rev. 57 (1940) 1087

[29] D.R. Corson, K.R. MacKenzie, E. Segrè: Phys. Rev. 58 (1940) 672/8

[30] J.G. Hamilton, M.H. Soley: Proc. Nat. Acad. Sci. 26 (1940) 483/9

[31] J.G. Hamilton, M.H. Soley: J.Appl. Phys. 12 (1941) 314

[32] G.L. Johnson, R.F. Leininger, E. Segrè: J. Chem. Phys. 17 (1949) 1/10

[33] E.H. Appelman: Chemical Properties of Astatine, UCRL-9025, Berkeley (1960); C.A. 54 (1960) No. $16998 \mathrm{e}$

[34] E.H. Appelman: J. Am. Chem. Soc. 83 (1961) 805/7

[35] V.A. Khalkin**, Yu.V. Norseyev, V.D. Nefedov, M.A. Toropova, V.I. Kuzin: Dok1. Akad. Nauk SSSR $\underline{195}$ (1970) $623 / 5$

[36] G.A. Nagy, P. Gróz, V.A. Halkin, Do-Kim Toung, J.V. Norszejev: KFKI Közl. 18 (1970) 173/6; C.A. 75 (1971) No. $14412 \mathrm{w}$

[37] E. Kroó, I. Dudova, V.A. Halkin: Magy. Kém. Foly. 82 (1976) 1/10; C.A. 84 (1976) No. $127325 \mathrm{z}$

[38] I. Dreyer, R. Dreyer, Yu.V. Norseev, V.A. Chalkin: Radiochem. Radioanal. Lett. 33 (1978) 291/300

[39] I. Dreyer, R. Dreyer, V.A. Chalkin: Radiochem. Radioanal. Lett. 35 (1978) $257 / 62$

[40] G.A. Nagy, V.A. Halkin, J.V. Norszejev: Magy. Kém. Foly. 73 (1967) $191 / 4 ;$ C.A. 67 (1967) 50005j

[41] B.N. Belyaev, Van Yun-Yui, E.N. Sinotova, L. Német, V.A. Khalkin: Radiokhimiya $\underline{2}$ (1960) 603/13

[42] M. Bochvarova, Do Kim Toung, I.V. Dudova, Yu.V. Norseyev, V.A. Khalkin: Radiokhimiya 14 (1972) 858/65

[43] K. Rössler, W. Tornau, G. Stöcklin: J. Radioanal. Chem. 21 (1974) $199 / 209$

[44] G.-J. Meyer, K. Rössler: Radiochem. Radioanal. Lett. 25 (1976) $377 / 90$

[45] R. Dreyer, I. Dreyer, F. Rösch: Z. Chem. 22 (1982) 54/6; C.A. 96 (1982) No. $150056 \mathrm{u}$

\footnotetext{
*Yu.V. Norseyev, Yu.V. Norseev, J.W. Norseev, J.V. Norszejev are the different transliterations of the seme name.

**V.A. Khalkin, W.A. Chalkin, V.A. Halkin are the different transliterations of the same name.
} 
[46] Do Kim Tuong, I.V. Dudova, V.A. Khalkin: Radiokhimiya 14 (1972) 766/7

[47] A.H.W. Aten, Jr., T. Doorgeest, U. Hollstein, H.P. Moeken: Analyst 77 (1952) $774 / 8$

[48] A.H.W. Aten, Jr., J.G. van Raaphorst, G. Nooteboom, G. Blasse: J. Inorg. Nucl. Chem. 15 (1960) 198/9

[49] I. Dreyer, R. Dreyer, Yu.V. Norseev, V.A. Chalkin: Radiochem. Radioanal. Lett. 33 (1978) 281/90

[50] I. Dreyer, R. Dreyer, V.A. Chalkin: Radiochem. Radioanal. Lett. 36 (1978) $389 / 98$

[51] M. Lefort, G. Simonoff, X. Tarrago: Bull. soc. chim. France (1960) $1726 / 7$

[52] G.A. Nagy, V.A. Halkin: Magy. Kém. Foly. 81 (1975) 33/5; C.A. 82 (1975) No. $116686 \mathrm{a}$

[53] K. Berei, L. Vasáros: in: S. Patai, Z. Rappoport, The Chemistry of Functional Groups, Suppl. D, Part 1, Wiley Interscience, New York 1983, pp. $405 / 40$

[54] H.M. Neumann: J. Inorg. Nucl. Chem. 4 (1957) 349/53

[55] L. Lindner, G.A. Brinkman, T.H.G.A. Suèr, A. Schimmel, J. Th. Veenboer, F.H.S. Karten, J. Visser, C.J. Leurs: in: Radiopharmaceuticals and Labelled Compounds, Vol. 1, IAEA, Vienna 1973, pp. 303/16

[56] C. Aaij, W.R.J.M. Tschroots, L. Lindner, T.E.W. Feltkamp: Int. J. Appl. Radiat. Isot. 26 (1975) 25/30

[57] G.-J. Beyer, R. Dreyer, H. Odrich, F. Rösch: Radiochem. Radioanal. Lett. 47 (1981) $63 / 5$

[58] V. Doberenz, D.D. Nhan, R. Dreyer, M. Milanov, Yu.V. Norseyev, V.A. Khalkin: Radiochem. Radioanal. Lett. 52 (1982) 119/27

[59] B. Eichler: Radiochem. Radioanal. Lett. 22 (1975) 147/55

[60] V.M. Vakhtel, G.V. Vinel, Ts. Vylov, I.I. Gromova, A.F. Novgorodov, Yu.V. Norseyev, V.A. Khalkin, V.G. Chumin: Radiokhimiya 18 (1976) 886/93

[61] V.M. Vakhtel, G.V. Vinel, Ts. Vylov, I.I. Gromova, A.F. Novgorodov, Yu.V. Norseyev, V.G. Chumin, V.A. Khalkin: Isotopenpraxis 12 (1976) $441 / 6$

[62] G.-J. Meyer: Chromatographie trägerfreier anorganischer Formen von Jod-123 und Astat-211 und ihre Verwendung zur Halogenierung von Uracil und Desoxyuridin, Ber. Kernforschungsanlage Jülich, Jül-1076-NC (1974) 61 pp.; C.A. 82 (1975) No. $78910 z$

[63] G.-J. Meyer, K. Rössler, G. Stöcklin: Zur Reaktivität anorganischer Formen des Radioelementes Astat bei der Markierung von einfachen aromatischen Systemen und Biomolekülen, AED-Conf. 404-029 (1975) 9 pp.; C.A. 85 (1976) No. $139398 j$

[64] G.-J. Meyer: Zur Reaktivität und Selektivität anorganischer Formen des Radioelementes Astat bei Substitutionsreaktionen an aromatischen Systemen, Ber. Kernforschungsanlage Jülich, Jül-1418 (1977) 107 pp.; C.A. 88 (1978) No. 71113s

[65] E.H. Appelman: The Radiochemistry of Astatine, U.S. At. Energy Comn., NAS-NS 3012 (1960) 29 pp.; C.A. 54 (1960) No. $19191 \mathrm{e}$ 
[66] Yung-Yu Wang, V.A. Khalkin: Radiokhimiya $\underline{3}$ (1961) 662/6

[67] J. Merinis, Y. Legoux, G. Bouissières: Radiochem. Radioanal. Lett. 11 (1972) $59 / 64$

[68] K. Otozai, N. Takahashi: Radiochim. Acta 31 (1982) 201/3

[69] A.H.W. Aten, Jr.: in: O.R. Frisch, F.A. Paneth, F. Laves, P. Rosbaud, Beitrage zur Physik und Chemie des 20. Jahrhunderts, Vieweg, Braunschweig 1959 pp. $121 / 3$

[70] A.H.w. Aten, Jr.: Adv. Inorg. Chem. Radiochem. 6 (1964) 207/23

[71] E.H. Appelman: in: V. Gutman, MTP, Int. Rev. Sci., Inorg. Chem. Ser. I, Vol. 3, Butterworth, London 1972, pp. 181/98

[72] G.W.M. Visser, E.L. Diemer: Radiochim. Acta 33 (1983) 145/5]

[73] A.G. Maddock: in: Mellor's Comprehensive Treatise on Inorganic and Theoretical Chemistry, Suppl. II, Part I, Longmans, London 1956, pp. $1064 / 79$

[74] E.H. Appelman: J. Phys. Chem. 65 (1961) 325/31

[75] E.H. Appelman, E.N. Sloth, M.H. Studier: Inorg. Chem. $\underline{5}$ (1966) 766/9

[76] N.A. Golovkov, I.I. Gromova, M. Janicki, Yu.V. Norseyev, L. Vasáros: Radiochem. Radioanal. Lett. 44 (1980) $67 / 78$

[77] Fu-Chun Wang, Yu.V. Norseyev, V.A. Khalkin, Tao-Nan Ch'ao: Radiokhimiya $\underline{5}(1963) \quad 351 / 5$

[78] Do Kim Tuong, I.V. Dudova, V.A. Khalkin: Radiokhimiya 15 (1973) 548/53

[79] Yu.V. Norseyev, V.A. Khalkin: J. Inorg. Nucl. Chem. 30 (1968) 3239/43

[80] Fu-Chun An, N.G. Krylov, Yu.V. Norseyev, Tao-Nan Ch'ao, V.A. Khalkin: Soosazhdenie i Adsorbtsiya Radioaktivn. Elementov, Akad. Nauk SSSR, Otd. Obshch. i Tekhn. Khim. 1965 80/8; C.A. 63 (1965) No. $7695 f$

[81] Yu.V. Norseyev, Tao-Nan Ch'ao, V.A. Khalkin: Radiokhimiya $\underline{8}$ (1966) $497 / 504$

[82] I. Dreyer, R. Dreyer, V.A. Chalkin, M. Milanov: Radiochem. Radioanal. Lett. 40 (1979) 145/53

[83] R. Dreyer, I. Dreyer, M. Pfeiffer, F. Rösch: Radiochem. Radioanal. Lett. 55 (1982) 207/13

[84] R. Dreyer, I. Dreyer, F. Rösch, S. Fischer: Z. Chem. 23 (1983) 346/7; C.A. 100 (1984) No. 13379 p

[85] Yu.v. Norseyev, V.A. Khalkin, Tao-Nan Ch'ao: Izv. Sibirsk. Otd. Akad. Nauk. SSSR, Ser. Khim. Nauk 1965 21/7; C.A. 64 (1966) No. 16676g

[86] W.A. Chalkin, E. Herrmann: Isotopenpraxis 11 (1975) 333/40

[87] W.A. Chalkin, E. Herrmann, J.W. Norseev, I. Dreyer: Chem.-Ztg. 101 (1977) 470/81; C.A. 88 (1978) No. $28663 j$

[88] M. Milanov, V. Doberenz, V.A. Khalkin, A. Marinov: J. Radioanal. Nucl. Chem., Articles 83 (1984) 291/9

[89] L. Vasáros, Yu.V. Norseyev, D.D. Nhan, V.A. Khalkin: Radiochem. Radioanal. Lett. $\underline{54}$ (1982) 239/47 
[90] V.D. Nefedov, Yu.V. Norseyev, Kh. Savlevich, E.N. Sinotova, M.A. Toropova, V.A. Khalkin: Dokl. Akad. Nauk. SSSR 144 (1962) 806/9

[91] V.D. Nefedov, Yu.V. Norseyev, M.A. Toropova, V.A. Khalkin: Usp. Khim. $37(1968) \quad 193 / 215$

[92] E.H. Appelman: J. Am. Chem. Soc. 90 (1968) 1900/1

[93] W.M. Latimer: The Oxidation States of the Elements and their Potentials in Aqueous Solutions, Prentice-Hal1, New York 1953

[94] A. Cavallero: Contribution to the Study of Some Fundamental Chemical Properties of Astatine, Thesis, Université Catholique de Louvain, Louvain-la-Neuve 1981, $100 \mathrm{pp}$.

[95] M.F.C. Ladd, W.H. Lee: J. Inorg. Nucl. Chem. 18 (1961) 163/5

[96] G.A. Krestov: Radiokhimiya $\underline{4}$ (1962) 690/6

[97] V.P. Glushko, V.A. Medvedev, G.A. Bergman, L.V. Gurvich, V.S. Yungman, A.F. Vorobev, V.P. Kolesov, L.A. Reznitskii, B.V. Mikhailov,

G.L. Galchenko, M.Kh. Karapetyants: Termicheskie Konstanty Veschestv; Vyp. I, Nauka, Moscow, 1966; C.A. 65 (1966) No. 3097a

[98] G.A. Krestov: Izv. Vyssh. Uchebn. Zaved., Khim. Khim. Tekhnol. 6 (1963) 754/61; C.A. 60 (1964) No. 8712e

[99] G.A. Krestov: Teor. Eksperim. Khim. Akad. Nauk Ukr. SSR I (1965) $479 / 84 ;$ C.A. 64 (1966) No. 15087d

[100] G.A. Krestov: Izv. Vyssh. Uchebn. Zaved., Khim. Khim. Tekhno1. 6 (1963) $228 / 32$; C.A. 59 (1963) No. 12247 C

[101] D.S. Kaganyuk: Radiokhimiya 25 (1983) 814/6

[102] G.A. Krestov: Izv. Vyssh. Uchebn. Zaved., Khim. Khim. Tekhnol. 11 (1968) 762/5; C.A. 70 (1969) No. 7001e

[103] D.R. Stull, G.C. Sinke: Thermodynamic Properties of the Elements, No. $18 \mathrm{Adv}$. Chem. Ser., Am. Chem. Soc., Washington 1956

[104] V. Gopal: Curr. Sci. 36 (1967) 456/7

[105] L.A. Cole, J.P. Perdew: Phys. Rev. A 25 (1982) 1265/71

[106] H. Hotop, W.C. Lineberger: J. Phys. Chem. Ref. Data 4 (1975) $539 / 76$

[107] G.A. Krestov: Izv. Vyssh. Ucheb. Zaved., Khim. Khim. Tekhnol. 10 (1967) 391/7; C.A. 68 (1968) No. 7040a

[108] J.F. Durand: Bull. soc. chim. France 3 (1936) 1382/8

[109] R.E. Honig, D.A. Kramer: RCA. Rev. 30 (1969) 285/305; C.A. 71 (1969) No. $64413 \mathrm{k}$

[110] R.C. Weast, M.J. Astle: CRC Handbook of Chemistry and Physics, 62nd Ed., CRC Press, Boca Raton 1981-1982, p. B-7

[111] Ya.I. Gerasimov, V.M. Glazov, V.B. Lazarev, V.V. Zharov, A.S. Pashinkin: Dokl. Akad. Nauk SSSR 235 (1977) $846 / 9$

[112] Yu. Ya. Kharitonov, O.V. Bazileva, T.V. Gerzha: Izv. Vyssh. Uchebn. Zaved., Khim. Khim. Tekhnol. 22 (1979) 939/43; C.A. 91 (1979) No. 199848 q

[113] J. Drowart, R.E. Honig: J. Phys. Chem. 61 (1967) 980/5 
[114] S.G. Kim: Zh. Fiz. Khim. 53 (1979) $736 / 7$

[115] E.R. Lippincott, M.O. Dayhoff: Spectrochim. Acta 16 (1960) $807 / 34$

[116] E. Clementi, D.L. Raimondi, W.P. Reinhard: J. Chem. Phys. 47 (1967) $1300 / 7$

[117] K.S. Krasnov: Zh. Neorg. Khim. 3 (1958) 1993/8

[118] W.H. Zachariasen: in: G.T. Seaborg, J.J. Katz, The Actinide Elements, McGraw-H111, New York 1954, pp. $769 / 96$

[119] L. Genov: Zh. Obsch. Khim. 29 (1959) $689 / 91$

[120] A.N. Zhitomirskil: 2h. Strukt. Khim. 11 (1970) 1082/6

[121] H.D.B. Jenkins, K.P. Thakur: J. Chem. Ed. 56 (1979) 576/7

[122] G.A. Korablev: Zh. Strukt. Khim. 6 (1965) 323/4

[123] L.H. Ahrens: Geochim. et Cosmochim. Acta 2 (1952) 155/69; C.A. 46 (1952) No. $8475 a$

[124] R. McLaughlin: J. Opt. Soc. Am. 54 (1964) 965/7

[125] Ts. Vylov, N.A. Golovkov, K.Ya. Gromov, I.I. Gromova, A. Kolachkovsky, M.Ya. Kuznetsova, Yu.V. Norseyev, V,G. Chumin: Izv. Akad. Nauk SSSR, Ser. Fiz. 38 (1974) $701 / 9$

[126] Ts. Vylov, N.A. Golovkov, M. Gonusek, M.Ya. Kuznetsova, Yu.V. Norseyev, H.G. Ortlepp, V.G. Chumin: Izv. Akad. Nauk SSSR, Ser. Fiz. 42 (1978) $765 / 72$

[127] E. Storm, H. Israel: Nucl. Data Tables A7 (1970) 565/681

[128] S. Hangström, C. Nordling, K. Siegbahn: in: K. Siegbahn, Alpha-, Betaand Gamma-Ray Spectroscopy, Vol. 1, North-Holland Publ. Co., Amsterdam 1968 , pp. $845 / 56$

[129] J.A. Bearden: Rev. Mod. Phys. 39 (1967) 78/124

[130] J.A. Bearden, A.F. Burr: Rev. Mod. Phys. 39 (1967) 125/42

[131] F.T. Porter, M.S. Freedman: J. Phys. Chem. Ref. Data 7 (1978) 1267/84

[132] K.D. Sevier: At. Data Nucl. Data Tables 24 (1979) 323/71.

[133] W. Lotz: J. Opt. Soc. Am. 60 (1970) 206/10

[134] J.P. Desclaux: At. Data Nucl. Data Tables 12 (1973) $311 / 406$

[135] Keh-Ning Huang, M. Aoyagi, M.H. Chen, B. Crasemann, H. Mark: At. Data. Nucl. Data Tables 18 (1976) 243/91

[136] M.H. Chen, B. Crasemann, M. Aoyagi, Keh-Ning Huang, H. Mark: At. Data Nuc1. Data Tables 26 (1981) 561/74

[137] W. Bambynek, B. Crasemann, R.W. Fink, H.-U. Freund, H. Mark, C.D. Swift, R.E. Price, P.V. Rao: Rev. Mod. Phys. 44 (1972) $716 / 813$

[138] M.O. Krause: J. Phys. Chem. Ref. Data 8 (1979) 307/27

[139] B. Crasemann, M.H. Chen, V.O. Kostroun: Phys. Rev. A 4 (1971) 2161/64

[140] M.H. Chen, B. Crasemann, V.O. Kostroun: Phys. Rev. A 4 (1971) 1/7 
[141] M.O. Krause, J.H. Oliver: J. Phys. Chem. Ref. Data 8 (1979) 329/38

[142] A. Sommerfeld: Atombau und Spektrallinien, I. Band, Friedr. Vieweg, Braunschweig 1944

[143] U.D. Misra, R.N. Singh, B.G. Gokhale: J. Phys. B: Atom. Molec. Phys. 12 (1979) $1775 / 80$

[144] B.G. Gokhale, U.D. Misra: J. Phys. B: Atom. Molec. Phys. 11 (1978) $2077 / 86$

[145] B.G. Gokhale, U.D. Misra: J. Phys. B: Atom. Molec. Phys. 10 (1977) $3599 / 606$

[146] B.D. Padalia: J. Phys. B: Atom. Molec. Phys. $\underline{2}$ (1969) 811/3

[147] B.D. Padalia, S.G. Phadnis: J. Phys. B: Atom. Molec. Phys. $2 \underline{2}$ (1969) $1094 / 6$

[148] A.F. Burr, J.K. Carson: J. Phys. B: Atom. Molec. Phys. $\underline{7}$ (1974) 451/9

[149] C.H.D. Clark: Trans. Faraday Soc. 33 (1937) 1398/401

[150] K. Majumdar, Y.P. Varshni: Indian J. Phys. 28 (1954) 103/8

[151] z. Hussain: Can. J. Phys. 43 (1965) 1690/2

[152] S.P. Tandon, M.P. Bhutra, P.C. Mehta: Z. phys. Chem. (Leipzig) 245 (1970) $230 / 5$

[153] н. Dunken, н. Maller: z. Chem. 3 (1963) 73

[154] G. Herzberg: Molecular Spectra and Molecular Structure, I. Spectra of Diatomic Molecules, D. Van Nostrand, Toronto 1953 




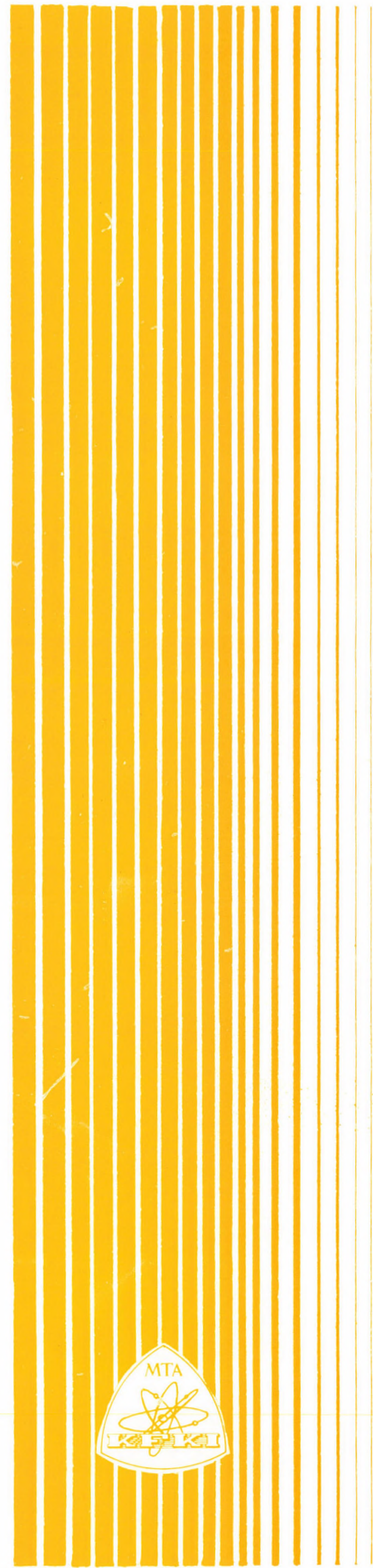

Kiadja a Központi Fizikai Kutató Intézet Felelós kiadó: Gyimesi zoltán

Szakmai lektor: Csatóné Nagy G. Ágnes Nyelvi lektor: Harvey Shenker Gépelte: Végvári Istvánné

Példányszám: 69 Törzsszám: 85-143 Készuilt a KFKI sokszorositó üzemében

Felelós vezetó: Töreki Béláné

Budapest, 1985. április hó 